\title{
An introduction to the avian gut microbiota and the effects of yeast- based prebiotic-type compounds as potential feed additives
}

\author{
Stephanie M. Roto, Peter M. Rubinelli and Steven C. Ricke* \\ Department of Food Science, Center for Food Safety, University of Arkansas, Fayetteville, AR, USA
}

The poultry industry has been searching for a replacement for antibiotic growth promoters in poultry feed as public concerns over the use of antibiotics and the appearance of antibiotic resistance has become more intense. An ideal replacement would be feed amendments that could eliminate pathogens and disease while retaining economic value via improvements on body weight and feed conversion ratios. Establishing a healthy gut microbiota can have a positive impact on growth and development of both body weight and the immune system of poultry while reducing pathogen invasion and disease. The addition of prebiotics to poultry feed represents one such recognized way to establish a healthy gut microbiota. Prebiotics are feed additives, mainly in the form of specific types of carbohydrates that are indigestible to the host while serving as substrates to select beneficial bacteria and altering the gut microbiota. Beneficial bacteria in the ceca easily ferment commonly studied prebiotics, producing short-chain fatty acids, while pathogenic bacteria and the host are unable to digest their molecular bonds. Prebioticlike substances are less commonly studied, but show promise in their effects on the prevention of pathogen colonization, improvements on the immune system, and host growth. Inclusion of yeast and yeast derivatives as probiotic and prebiotic-like substances, respectively, in animal feed has demonstrated positive associations with growth performance and modification of gut morphology. This review will aim to link together how such prebiotics and prebiotic-like substances function to influence the native and beneficial microorganisms that result in a diverse and well-developed gut microbiota.

Keywords: poultry, microbiota, lactobacillus, Bifidobacterium, yeast

\section{Introduction}

Poultry production in the past century has transitioned from predominantly breeding layers to breeding a mixture of both layers and broilers, based on the evolution of consumer demand (1-3). Success in the optimization of different broiler lines is due to genetics as well as optimizing diets with more precise nutritional formulations $(4,5)$. Comparison of individual genetic lines has revealed differing intestinal development, feed intake, and digestibility traits among other characteristics, which may impact performance (6-9). Improved diets have allowed broilers to reach their optimum body weight and feed conversion rate while minimizing mortality. Comparing poultry diets from the 1950s to those of the 1990s and 2000s illustrates the progress made $(10,11)$. For example, broiler 
chickens raised on a typical diet in 1957 had an average weight of 1,430 $\mathrm{g}$ at 84 days of age, whereas broilers fed a diet from 2001 yielded an average weight of 5,520 $\mathrm{g}$ at the same age. The feed conversion ratio in 2001 (2.68) was also considerably better compared to 1957 (3.26) (11). The current poultry diet contains the appropriate balance of amino acids, fatty acids, major and trace minerals, energy, and protein necessary for optimum growth (12).

Supplementation of various biologics have been attempted to enhance poultry feed for maximum growth development and health. Antibiotics enhance growth and reduce pathogens and although the exact mechanisms remain unclear, numerous working hypotheses have been offered (13-17). Antibiotic incorporation into poultry feed has since been tightly restricted and/or omitted due to microbial antibiotic resistance, presumably originating from both poultry (among other livestock) and humans (18-20). Since the exclusion of antibiotics in diets, a number of alternative supplements have been tried (Table 1), including prebiotics (21).

A prebiotic, as defined by Gibson and Roberfroid (35), is "a non-digestible food ingredient that beneficially affects the host by selectively stimulating the growth and/or activity of one or a limited number of bacteria in the colon and thus improves health." This definition has been subsequently refined to include the requirements for resistance to the acidic gastric environment, gastric enzymes, gastrointestinal absorption, and fermentation by the gastrointestinal microbiota while stimulating growth of beneficial intestinal bacteria (22). Being indigestible by the upper gastrointestinal tract (GIT) enables it to enter the lower GIT as a substrate for health-promoting bacteria, such as bifidobacteria and lactobacilli, thereby modulating the microbiota (35). Many feed additives currently used do not fit wholly into the strict prebiotic classification; they may lack one or more of the criteria set by Roberfroid (22). Although these substances have differing modes of action compared to prebiotics, they have a similar end result of a healthy and mature GIT microbiome. They may inhibit pathogenic invasion, reduce pathogens in the environment, modulate the host immune response, or enhance the host GIT morphology to enable the host to better limit pathogens in the GIT lumen.
These substances will be referred to as prebiotic-like substances for the remainder of this review.

The objective of this review is to provide an overview of the effects of prebiotic-like substances, particularly those that are yeast-derived, while assessing the influence on microbial diversity of the poultry gut microbiota when using single or complex mixtures. In order to achieve this, both the gut microbiota as well as prebiotics is reviewed. Additionally, the characteristics of complex mixtures of prebiotic-like substances are assessed, including their effects on the gut development and physiology, the interactions that occur between host and microorganisms, and the potential use of prebiotic-like substances in creating a more healthy gut microbiota. This review includes findings from not only poultry but also human and animal models, which may provide insight into potential effects in poultry.

\section{Gut Microbiome: Terminology and Definitions}

The microbiota is defined as the diverse population of microorganisms in a given environment, while the microbiome can be defined by either its genetic or ecological capacities (36). Genetic diversity is the entire collection of genes of the microorganisms in an environment, while the ecological diversity is all the microorganisms that make up an ecosystem (36). The term "microflora," once commonly used, is now often replaced by "microbiota" to avoid the plant connotation from the suffix "flora." (36). Regardless of the term used, it is essential to use a modifying adjective when referring to a specific anatomical region. For example, "gut microbiome" is indicating only the microorganisms in the GIT. There are numerous microbiome sites in addition to the gut microbiome, as they can be any shared anatomical sites between a community of microorganisms (commensal, pathogenic, or symbiotic) (37-39). An oral microbiome, for example, is the community of microorganisms that interact with and live within the oral cavity. It has several distinct microbial habitats within the oral cavity (gingival, tongue, and teeth) and extensions of the oral cavity (esophagus, middle ear, and nasal passages). Each different habitat within the oral cavity has its own distinct bacterial

TABLE 1 | Commonly researched feed additives for host health, including growth promotion and pathogen prevention, used in animal feed, their modes of action, and reviews for references.

\begin{tabular}{|c|c|c|c|}
\hline Compound & What they do & How they work & $\begin{array}{c}\text { Reviews for } \\
\text { reference }\end{array}$ \\
\hline Prebiotic & $\begin{array}{l}\text { Food ingredient to act as substrate } \\
\text { for beneficial bacteria in the host GIT } \\
\text { microbiota }\end{array}$ & $\begin{array}{l}\text { Host consumes prebiotic and it endures through the GIT relatively intact } \\
\text { to the lower intestines where it selectively acts as substrate for beneficial } \\
\text { bacteria }\end{array}$ & $(22-24)$ \\
\hline Probiotic & $\begin{array}{l}\text { Live microbial feed supplements that } \\
\text { beneficially impact intestinal microbial } \\
\text { balance }\end{array}$ & $\begin{array}{l}\text { Competes with pathogenic bacteria to colonize the intestines; ferments } \\
\text { substrates to produce short-chain fatty acids; stimulates the immune } \\
\text { response of the host }\end{array}$ & $(23,25,26)$ \\
\hline Mannan-oligosaccharide & $\begin{array}{l}\text { Specific oligosaccharide that inhibits } \\
\text { pathogenic bacteria from binding the } \\
\text { mucosal epithelial lining }\end{array}$ & $\begin{array}{l}\text { Pathogens have receptors specific for mannan residues, the pathogenic } \\
\text { bacteria binds the mannan and does not bind to the host epithelial cells }\end{array}$ & $(27-29)$ \\
\hline Organic acid & Reduce the number of pathogens & $\begin{array}{l}\text { Undissociated form traverses the bacterial cell membrane; once inside the } \\
\text { bacterial cell, the organic acid dissociates to produce } \mathrm{H}^{+} \text {ions, which lowers } \\
\text { the } \mathrm{pH} \text {. The bacterial cell then has to expend its energy to restore it natural } \\
\text { balance rather than promote its own growth }\end{array}$ & $(30-34)$ \\
\hline
\end{tabular}


population in the form of complex biofilms (40). Research has shown that even the distinctive sites of the tongue - the dorsal and the lateral regions - possess differing bacterial profiles (41). Other frequently studied sites of microbiomes are the skin and the respiratory tract (42-44). The various regions and diversity among bacterial communities of the microbiota are indicative of the inherent complexity of microbiome research.

The gut microbiome is a widely studied topic because of its impact on health as well as its characteristic intricacy. The gut microbiome is home to one of the densest bacterial populations on earth, with numbers ranging from $10^{8}$ to $10^{14} / \mathrm{g}$ of digesta (45, 46). The microbiome encompasses biochemical and metabolic pathways not found in the host genome; this attests to the extent to which the microbiome has evolved (47). Microorganisms that comprise the gut microbiota have been found to directly impact the health of the host, providing protection against epithelial damage, aiding in digestion, and promoting development of a healthy immune system $(48,49)$. Commensal bacteria, in the GIT of animals, aid in absorption of nutrients as well as enhance nutrient utilization (50). Additionally, research conducted thus far has shown that earlier development of a mature and diversified microbiota leads to better growth and fewer health issues, such as obesity, allergies, and asthma $(51,52)$. This is in part due to healthy competition among microorganisms.

\section{Avian Gut Anatomy, Structure, and Functionality}

For a thorough understanding of the microbial communities that inhabit the GIT of poultry and the effects they may have, a brief description of the poultry GI system is warranted. The GIT of poultry, chickens specifically, begins at the esophagus and continues down past the crop, proventriculus, and gizzard, through the intestines (duodenum, jejunum, ileum, and ceca), and ends at the colon and cloaca $(53,54)$. The gut microbiota generally refers to the intestinal regions and the studies included in this review focus on the duodenum, jejunum, ileum, ceca, and fecal contents as well as the structural characteristics to illustrate the gut microbiome of poultry. The ceca and their contents are most often studied based on their slow passage rate [comparatively, gut transit time from mouth to the lower ileum is approximately $3 \mathrm{~h}$, while contents may be retained in the ceca as long as $35 \mathrm{~h}(55-57)]$ as it exhibits the most diversification in the bacterial communities it harbors, in turn, indicating its impact on host health (54).

The intestines are multi-layered tubes, containing epithelial, muscular, and mucosal layers (58). Each section of the intestine, from the most proximal duodenum passing through the jejunum and out to the most distal ileum, contains numerous folds and is lined with villi and crypts. The villi are finger-like projections on the surface of the mucosal lining responsible for increasing surface area to maximize nutrient absorption and containing a meshwork of capillaries to allow nutrients entry into the bloodstream (59). When moving in the distal direction from the duodenum down toward the ileum, the mucosal lining reduces in thickness. The villi length and crypt depth also decrease in a continual gradation, which supports the notion of the majority of nutrient absorption occurring in the small intestine (58). Reduced intestinal weight is associated with improved nutrient absorption (60). Microscopic analysis has revealed that the reduction of intestinal weight is due to thinning of the epithelial lining rather than to the reduction in intestinal length, which is suggested to allow for improved nutrient absorption $(61,62)$.

The pancreas functions in hydrolysis of macromolecules, releasing digestive enzymes into the duodenum responsible for the hydrolysis of proteins, carbohydrates, and lipids supplied by the diet. In addition to enzyme production, the pancreas also produces hormones and bicarbonate that aid in metabolism regulation and buffer the intestinal $\mathrm{pH}$, respectively $(59,63)$. The addition of enzymes to the duodenum allows for the small intestine to be the primary site of nutrient digestion and absorption. Having a general understanding of the digestive system of poultry allows for a more thorough insight into how microorganisms may impact GIT physiology. Turk (58) provides a more encompassing review of the entire avian GIT.

\section{Avian Gut Microbiome Characterization}

Characterization of microbial communities native to the poultry GIT began in 1901 and has since revealed these communities to be both diverse and dynamic (64). As biased culture-based methods advanced to molecular and sequencing techniques, a broader, more comprehensive representation of the microbiome has been recognized $(64,65)$. Researchers have attempted to determine a bacteriological profile of the poultry GIT via 16 S rRNA gene-based studies; the findings have demonstrated that the majority of the $16 S$ rRNA sequences in the cecal contents are not-yet-identified bacterial species $(64,66,67)$. These discoveries uncovered the shortcomings of previously employed culture-based methods. For example, comparison of results obtained from Zhu et al. (64) and Rada et al. (68) found differing levels of Bifidobacteriaspecies present in untreated chicken cecal contents. Zhu et al. (64) used temporal temperature gradient gel electrophoresis followed by sequencing of the 16S rRNA fragments, while Rada et al. (68) used selective media; the experimental designs of both were comparable. The works of Zhu et al. (64) and Rada et al. (68) are two such examples for the characterization of the GIT microbiome; various techniques have been attempted to ascertain the microbial populations present in the different regions of the intestinal tract (Table 2).

Each area of the intestinal tract harbors distinct microbial communities. For example, the cecal contents exhibit greater levels of Clostridiaceae-related sequences as opposed to the ileum where more abundance of Lactobacillus-related sequences occurs (75). Apajalhti et al. (70) used $\mathrm{G}+\mathrm{C}$ content to demonstrate similar results: the measurement of bacterial communities present in the ceca and ileum exhibited considerable variation when comparing the two $\mathrm{G}+\mathrm{C}$ profiles. Variation in microbial communities is not only limited to differing organs, there is also a temporal factor in the nature of the microbiome (76). The cecal contents of younger birds appeared to possess more transient communities that matured into communities with much greater complexity, while the ileum indicated an overall constant microbiome except at days 3 and 49 (the youngest and oldest sampling points) (75). The response to newly introduced microorganisms also appears 
TABLE 2 | Research conducted on commensal bacteria in poultry GIT based on location.

\begin{tabular}{|c|c|c|c|c|c|}
\hline Host & Site(s) & Age(s) & Commensal or pathogenic & Method of investigation & Reference \\
\hline Chicken & lleum, cecum & 7,13 days & Commensal & $\begin{array}{l}\text { PCR-based DGGE; } 16 S \text { rRNA gene } \\
\text { library analysis; qPCR }\end{array}$ & (69) \\
\hline Chicken & lleum & $4,8,14,21,35$ days & Commensal & DGGE; RFLP & (6) \\
\hline Chicken & lleum, cecum & 4 weeks & Commensal & Percent $\mathrm{G}+\mathrm{C}$ profiling & $(70)$ \\
\hline Chicken & Cecum, intestines & $4,14,25$ days & Pathogenic & Primers (species-specific) of $16 \mathrm{~S}$ rDNA & $(71)$ \\
\hline Chicken & Cecum & 1 day, $1,2,4,6$ weeks & Commensal & TTGE; 16S rRNA gene sequencing & $(64)$ \\
\hline Chicken & Crop, ileum, cecum, rectum & 40,41 days $^{a}$ & Commensal & 16S rDNA sequencing & $(72)$ \\
\hline Chicken & lleum, cecum & 28 days & Commensal & FISH with $16 \mathrm{~S}$ rRNA oligonucleotides & $(73)$ \\
\hline Chicken & Crop, duodenum, colon & 2 months & Commensal & FCM-FISH & $(74)$ \\
\hline
\end{tabular}

alndicates differing rearing methods: conventionally raised and organically raised, respectively.

to be dependent on sex of the host when analyzed in a mouse model; male and female GIT microbiota influence the metabolic activities and immune system differently (77). The concept of host factors affecting microbial diversity offers the opportunity to use established and healthy microbiomes to generate a working GIT microbial profile. However, this may prove to be quite challenging as it has been found that chickens interacting together in the same conditions, receiving the same feed, and of the same age and sex still display uniquely dominant bacterial communities (78). Although the exact quantities and qualities of a healthy microbiota have yet to be determined, a relationship appears to exist between the establishment of a mature intestinal microbiome and positive impacts on the host, resulting in improved growth and health (79).

\section{Avian Gut Microbiome-Metabolic Activities}

The poultry GIT is essentially coated in a dense layer of commensal bacteria in a diverse array of niches. Generally, the most complex microbial communities are found in the crop and the ceca. There is less colonization in the intestines based on the unfavorable environment. For example, the duodenum contains numerous enzymes, high concentrations of antimicrobial compounds, such as bile salts, and also has a rapidly changing environment due to reflux from the jejunum up to the gizzard (80). Traveling further down the GIT, the ileum and ceca become more favorable environments with fewer enzymes and antimicrobial compounds; this is reflected in the increased concentrations of commensal bacteria, around $10^{9}$ and $10^{11}$ bacteria/g, respectively (46). The unique anatomical structure of the cecum allows for the occupancy of fermentable substrates not widely available in different areas of the GIT; this enables differing microorganisms to reside and produce large amounts of energy metabolites to aid in achieving the bird's energy requirements (81).

Research profiling whole body energy consumption patterns has attributed $22.8 \%$ to being utilized by the GIT and liver (82), but not all of that energy is actually being used by and for the host. It was reported that the presence of GIT microbiota significantly increased the dietary metabolizable energy in the broiler chicken host, indicating that the microbiota are responsible for utilizing the additional dietary energy (83). The commensal bacterial communities utilize nutrients from the host's diet as energy sources, making those nutrients unavailable to the host. However, they are able to produce short-chain fatty acids (SCFAs) from the fermentation of those nutrients (84). Research suggests the GIT microbiota aid in digestion and energy release from starch and fibrous contents, especially in the ceca. It is proposed that the amounts and types of SCFAs that are generated in the ceca are in proportion to differing starches that enter the ceca (85). Although SCFAs serve as additional energy sources for the host, it is suggested that only a proportion (up to 25\%) of the overall SCFA energy is recovered by the bird $(85,86)$. In high-fiber and low-energy diets, bacterial digestion of the fiber also releases energy in the form of SCFA $(84,87)$. Along with generating accessible energy, the gut microbiome is associated with conservation of energy when nutrient sources (proteins, fats, and sugars) are low $(88,89)$. The production and absorption of SCFAs in the intestine are occurring continuously, with more or less being produced due to alterations in the diet or cecal microbiome (85).

Conversely, the resident microbiome has also been associated with unfavorable effects to the host's utilization of dietary energy. Although the presence of the GIT microbiota has indicated a significant increase in levels of metabolizable energy in conventionally raised broiler chickens when compared to germfree (89), the metabolizable energy is attributed to the products generated by the GIT microbiota. The variation can be associated with the digestibility of those energy sources (dietary fiber and starches) being broken down into monosaccharides and SCFA. The SCFA are portrayed as possessing a high metabolic energy value, yet they are inefficiently utilized by the host. Therefore the levels of SCFA present are not reflective of the net deposition of energy to the host $(86,89)$. Another potential explanation may be that the presence of the gut microbiota increases the cost of energy by altering the rate of energy-consuming reactions (89, 90). For example, pathogens attach to the epithelial lining, alter its integrity and function, and in turn stimulate the renewal of epithelial lining, which increases the amount of dietary energy spent on gut maintenance $(27,91)$. It has also been observed that conventionally raised birds have higher energy requirements for maintenance when compared to germfree birds (92). This may be due to the addition of the host's microbiota usage of metabolizable energy, or the host's microbiota making dietary energy unavailable to the host (92). 


\section{Avian Microbiome and Foodborne Pathogens}

The complex lining of the lower intestines with bacteria serves as a barrier against colonization of pathogenic bacteria, which if allowed to occur, could lead to infection. The bacteria that settle first in the lining of the intestines necessitate that any other microorganisms in search of new residence must compete for space and nutrients in order to survive and colonize $(80,93,94)$. Establishing the early foundation of a mature GIT microbiota has been associated with prevention of infection with pathogens, namely Salmonella, by beneficial bacteria outcompeting the pathogenic bacteria for space and nutrients (95-98). In nature, chicks are hatched in the presence of maternal fecal contents, allowing rapid colonization of members from the maternal gut microbiome (25). In an attempt to colonize newly hatched chicks with a mature and healthy microbiome that will discourage pathogenic bacteria from colonizing, chicks have been experimentally inoculated with competitive exclusion culture mixtures (97, 99-102). Introduction of the competitive exclusion cultures has proven to be effective in protecting young chicks from enteric pathogens and several reviews have been written on various aspects of this research (103-106).

As previously mentioned, commensal bacteria produce SCFA, which are recognized as having growth-inhibiting effects on enterobacteriaceae (107-109). The presence of the SCFA causes a drop in cytoplasmic $\mathrm{pH}$, which is recognized as a contributing factor to the inhibition of pathogen growth (110). Although the mechanisms of SCFAs are not well understood, they are known to exhibit bactericidal and bacteriostatic properties $(30-32,111)$. Russell (30) suggested that it is not only the result of a drop in $\mathrm{pH}$ caused by the SCFA but also the uncoupling reactions produced by the translocation of protons by SCFA that contribute to the growth inhibition effects seen. In accordance with this notion, Davidson et al. (112) suggested that because the fatty acids produced are weak acids, they are effective as antimicrobials in their undissociated forms as they are able to easily diffuse through the cytoplasmic membrane of the microorganism. The fatty acids dissociate into anions and protons once in the cytoplasm of the microorganism (maintained relatively neutral or slightly alkaline), in turn decreasing the $\mathrm{pH}$ and causing conformational changes of cytoplasmic proteins, enzymes, and nucleic acids. In an attempt to reestablish a neutral/slightly alkaline $\mathrm{pH}$, microorganisms utilize ATP-dependent pump systems to transport the anions and protons outside of the cell. This is in accordance with findings of Cherrington et al. (113), where incubation of Escherichia coli with propionic and formic acids resulted in reduced rates of macromolecular synthesis initially, yet it partially regained synthesis rates after continued incubation.

Anion accumulation is suspected to be another factor in uncoupling reactions that attributes to growth inhibition of bacteria in the presence of SCFA. It is suggested that the accumulation of acid anions causes an uncoupling effect of the electron transport chain from oxidative respiration (via the passage of molecules in their dissociated and undissociated forms, transferring protons into the cell to dissipate the proton motive force) as well as a chaotropic effect (disrupting hydrogen bonding in water causing macromolecules in solution to lose stability) that are accountable for the increased hydrogen ion leakage into the cell. The cell is unable to excrete hydrogen ions rapidly enough, making it difficult for the cell to regain its neutral/slightly alkaline intracellular $\mathrm{pH}(30,110,114,115)$. The intracellular increase in hydrogen is unable to counteract the accumulation of acid anions (116). Another inhibitor of bacterial growth by SCFA is the disruption of the membrane of a microorganism by means of permeabilization or intercalation, allowing for the release of macromolecules and the destabilization of the membrane $(117,118)$. However, there are instances of pathogenic bacteria acquiring resistance to SCFAs (32). For example, pre-incubation of Salmonella with high concentrations of SCFA at neutral $\mathrm{pH}$ resulted in an acid tolerance response and has also been demonstrated to be responsible for modulation of virulence gene expression and attachment/ invasion of in vitro tissue culture cells (119-122).

While the production of fatty acids is inhibitory to invading bacteria, studies suggested that the fatty acids are inactive against the species that produced them (123). Smulders et al. (124) found that acid-producing bacteria are tolerant to acids and in turn, the acidic environments that they generate. Therefore, the influences of the SCFAs produced by autochthonous bacteria may provide protection against pathogenic bacteria - Salmonella, coliforms, and Campylobacter - intent on colonizing in the intestine while leaving commensal bacteria unscathed (125). However, little else has been reported on the effects of the fatty acids on the producing species.

\section{Key Players in the Gut Microbiota}

In the past, the microorganisms colonizing the GIT were thought to be commensal, neither beneficial nor harmful to the host, as opposed to being mutualistic (37). However, numerous germfree experiments in various animal models have indicated the value of these indigenous microorganisms (126-128). There has been overwhelming data collected revealing the beneficial impacts on both host physiology as well as immunology $(75,129)$. Several studies have indicated that introducing a balance of beneficial microorganisms to the poultry microbiota improves body weight gain and feed conversion ratio as well as warding off common diseases in poultry, such as Newcastle disease and infectious bursal disease (130-132). However, in order to better promote strategies for increasing the presence of beneficial bacteria, those bacteria and their interacting counterparts must be identified.

Although being incredibly diverse, the most abundant microorganisms in the gut microbiota of poultry are primarily anaerobic (54). This is somewhat expected since there is little to no oxygen available as an electron acceptor in the lumen, although the concentration of oxygen is greater toward the epithelium, thus forcing bacteria to use fermentation to produce pockets of organic acids within the lumen (133). Moreover, Sun and O'Riordan (133) suggest that as a result of this environment, it is necessary to investigate SCFAs more in depth because bulk analysis does not reveal the true nature and spatial arrangement of these acids (which would further indicate the location and family of anaerobic bacteria). There is no consistent data available indicating the overall Gram status of poultry GIT microbiota. Investigation into 
the commensal bacteria present in an untreated chicken ceca has resulted in an array of bacterial communities (Gram-positive Y-branched, Gram-positive non-sporulating, Gram-negative) and may be attributed to the rearing conditions, chicken breed, diet, or even the cultivation and enumeration methods applied for bacterial characterization (125). Nevertheless, there are trends observed in available data investigating the microbial populations in broiler chickens grown in a conventional poultry flock and those raised under laboratory conditions $(76,134)$.

Lactobacilli and bifidobacteria are two of the more wellknown beneficial bacteria, however, there are numerous others: Bacillus, Enterococcus, E. coli, Lactococcus, Streptococcus as well as undefined mixed cultures (Table 3) (23). These bacteria are indigenous to the GIT, occupy space, and consume nutrients along the intestinal tract, limiting the colonization of pathogenic bacteria. In addition to competing for space and nutrients, these bacteria have been recognized for exporting bacteriocins, which can target and kill invading pathogens (133). All of these microorganisms fit under the umbrella term probiotics. Like prebiotics, probiotics also have specified criteria and characteristics: (1) non-pathogenic and of host origin, (2) resistant to gastric $\mathrm{pH}$ and processing/storage, allowing them to persist in the intestinal tract, (3) able to adhere to epithelial and mucosal membranes, (4) modulate immune responses, and (5) produce inhibitory compounds (23). It is the complexity and broad diversity of the beneficial microorganisms that make up the microbiome and allow for a mature and healthy host $(51,52)$.

Bacteria may be beneficial to the host by aiding in degradation of polysaccharides otherwise indigestible to the host. The monosaccharides produced can be subsequently broken down further into SCFAs and lactic acid (37). As previously mentioned, both lactobacilli and bifidobacteria are beneficial and indigenous to the human and chicken GIT (145). Lactobacilli are members of a group collectively referred to as lactic acid bacteria, which metabolize carbohydrates to produce lactic acid as the primary end product (146). Oligosaccharides are their main nutritional source, which is reflected in their residence in ecological niches rich in carbohydrate-containing substrates, most commonly plant material, spoiled or fermented foodstuffs, and mucosal membranes of humans and animals (147). Along with their broad range of habitats, lactobacilli are able to adapt to various conditions by altering their strictly fermentative metabolism accordingly; they may be obligately homofermentative, facultatively homofermentative, or obligately heterofermentative (148). Their fermentative status is based on the levels and proportions of end products they generate from fermentation of differing substrates (although other factors, such as chemical and physical environment, play a role in determining fermentative status). Obligately homofermentative indicates that their primary fermentation product is lactic acid (>85\%) generated by fermenting hexoses (149). Facultatively homofermentative indicates that they are capable of fermenting hexoses and pentoses using different pathways to generate lactic acid (although under low substrate concentration and strictly anaerobic conditions, they are capable of producing acetic acid, ethanol, and formic acid). Obligately heterofermentative lactobacilli ferment hexoses generating equimolar amounts of lactic acid, $\mathrm{CO}_{2}$, and acetic acid (148-150). Although the end products produced are a fair indication of fermentative status, they are not the sole factor. These microorganisms are aerotolerant and acidophilic, allowing for the GIT to be an optimal residence $(146,151)$.

Bifidobacteria are another well-documented example of beneficial bacteria. They are often associated with lactic acid bacteria for their production of lactic acid, however, they are phylogenetically distinct. Bifidobacteria are Gram-positive, heterofermentative, and non-motile (152). Like lactobacilli, bifidobacteria digest oligosaccharides to use as carbon and energy sources, to produce lactic acid, acetic acid, ethanol, and formic acid (153). They are not exclusive to the utilization of dietary compounds, they can also digest carbohydrates produced by other members of the GIT (154). Additionally, they are capable of internalizing simple sugars remaining in the environment, thus preventing pathogenic bacteria from utilizing them as a nutrient source (155).

Both lactobacilli and bifidobacteria are known to be members of the intestinal microbiota in animals and humans; their presence is important for the maintenance of the GIT microbiota (156-158). Being that lactobacilli and bifidobacteria are autochthonous and dominant in the GIT, they can be utilized as a control method of pathogenic bacteria by competition, for example Clostridium perfringens (156). Lactobacilli and bifidobacteria possess characteristics that allow them to out-compete pathogenic bacteria. Various strains of lactobacilli adhere to intestinal epithelial-like cells and exhibit antimicrobial activity against bacteria typically found in the (human) GIT (157). A link between the lactobacillus strain's $\mathrm{pH}$ tolerance and antimicrobial properties has been reported, both in vitro and in vivo (157).

TABLE 3 | Suggested microorganisms for potential probiotic use based on various characteristics.

\begin{tabular}{|c|c|c|c|c|}
\hline Microorganism & Host & Site isolated & Rationale & Reference \\
\hline Enterococcus faecium & Chicken & Intestines & Bacteriocin-producing ability & $(135)$ \\
\hline Pediococcus pentosaceus & Chicken & Intestines & Bacteriocin-producing ability & $(135)$ \\
\hline Mixed culture ${ }^{a}$ & Chicken & Cecum & Inhibition ability of Salmonella & $(99,136-139)$ \\
\hline Lactobacillus reuteri & Chicken & GIT & $\beta$-glucanase gene enhances growth and nutrient digestion & $(140)$ \\
\hline Lactobacillus fermentum & Chicken & GIT & Intestinal adherence, pathogen inhibition, tolerance to gastric enzymes & $(141)$ \\
\hline Bifidobacterium longum & Chicken & GIT & Anti-Campylobacter activity & $(142)$ \\
\hline Streptococcus faecium & Chicken & GIT & $\begin{array}{l}\text { Impacts of body weight, feed conversion, carcass yield, Salmonella } \\
\text { colonization }\end{array}$ & $(143)$ \\
\hline Streptococcus bovis & Cattle & Rumen & Inhibition ability of Salmonella & $(144)$ \\
\hline
\end{tabular}

aMixed culture composed of 29 cecal bacterial strains that have shown to inhibit Salmonella colonization. 
Different species of lactobacilli and bifidobacteria produce various antimicrobial agents, which allow them to be inhibitory toward pathogenic bacteria. Many species of lactobacilli and bifidobacteria produce SCFA; the production of these acids causes a drop in intestinal $\mathrm{pH}$. The lowered $\mathrm{pH}$ level extends the lag phase for sensitive microorganisms (124). The undissociated forms of these acids are able to penetrate the microbial cell and hinder metabolic functions (further information on the mechanisms of these acids was discussed in a previous section of the current review). Another end product generated from lactobacilli and bifidobacteria is $\mathrm{CO}_{2}$, which has demonstrated inhibition of microbial growth (149). The inhibitory mechanism of $\mathrm{CO}_{2}$ is unclear, although Eklund (159) was able to rule out the proposed mechanism of $\mathrm{CO}_{2}$ accumulation in the membrane of the microorganisms, physically interrupting the bacterial membrane. Growth of E. coli, Bacillus subtilis, Pseudomonas aeruginosa, and Bacillus cereus has been shown to be inhibited in the presence of $\mathrm{CO}_{2}$ at various concentrations (159). Succinic acid is produced by both lactobacilli and bifidobacteria, although at minimal levels $(160,161)$, and is associated with antibacterial activities in a multitude of environments $(162,163)$. Diacetyl is an end product of lactobacilli that exhibits antimicrobial effects. It is suggested that diacetyl is more effective in a lower $\mathrm{pH}$ ( $\leq 7)$ causing it to be lethal to Gram-negative bacteria and inhibitory of yeasts (164). Bacteriocins, produced by lactobacilli, may have a narrow or broad range of activity. Lindegren and Dobrogosz (149) have reviewed the various antimicrobial agents produced by lactic acid bacteria in more detail.

Overgrowth of any single type of bacteria can have unfavorable effects on the host. Lactobacilli are considered beneficial bacteria, however, antibiotic growth promoters that stimulate improved growth of broilers were also associated with heightened sensitivity of lactobacilli to those antibiotics (165). Although the host may benefit from the commensal bacteria competing with pathogenic bacteria, an overgrowth of commensal bacteria can be detrimental to the host by excessive uptake of nutrients making them unavailable to the host (166). Additionally, overgrowth of lactobacilli can impair host fat absorption by not allowing proper biotransformation - deconjugation and dehydroxylation - of bile acids (14). Overgrowth of bacteria can also lead to overproduction of fermentation end products to the detriment of the host. For example, overgrowth of Streptococcus bovis, a commensal lactic acid-producing bacteria can generate considerable acid production and a concomitant lowering of the surrounding environment $\mathrm{pH}$. This sequence can be advantageous for competing against pathogens. Consequently, under in vitro incubation conditions in co-culture with Salmonella typhirmurium growth of $S$. bovis can behave as a probiotic and directly limit Salmonella growth as a function of carbon source and time of inoculation (144). However, when easily fermented carbohydrates are fed to ruminants, excessive $S$. bovis growth can occur in the rumen resulting in rapid lactic acid overproduction, subsequent lowering of the ruminal $\mathrm{pH}$, and the eventual development of a harmful ruminal lactic acidosis condition in the animal (167). Therefore, even though $S$. bovis might be considered a gut commensal organism, and in some cases a probiotic candidate, it can also be associated with host clinical disease states, such as bacterial endocarditis and colon cancer in humans (144).

\section{Introduction and History of Prebiotics}

The most widely accepted definition of prebiotics are nondigestible feed ingredients that are selectively fermented by beneficial bacteria in the lower GIT (capable of withstanding harsh conditions in the upper GIT) so as to provide energy to promote bacterial growth and metabolism in the colon which contributes to specific changes that lead to improved host health $(22,35,168)$. Colonic food is a non-digestible ingredient that makes it past the upper GIT and into the colon, serving as a substrate for non-specific bacterial inhabitants, both beneficial and harmful $(169,170)$. Not all colonic foods are necessarily prebiotics; the rationale for designating a compound as a prebiotic or not depends upon whether beneficial bacteria alone are able to digest it. Some miscellaneous compounds that serve as colonic food, but do not fall into the category of prebiotics because of the non-specific targeting of microbiome bacteria include resistant starch, non-starch polysaccharides, non-digestible oligosaccharides, and yeast fermentation products (171). There have been numerous studies conducted and reviews written covering common prebiotics and their beneficial impacts; therefore they will not be discussed in detail here (Table 4) (35, 172-174).

Some lesser-studied prebiotic-like compounds are Saccharomyces cerevisiae fermentation products (SCFPs) or yeast culture (YC) components; these compounds do not fall

TABLE 4 | Published reviews on the considerations of common prebiotics in various hosts.

\begin{tabular}{|c|c|c|c|}
\hline Prebiotic & Considerations & Host & Reference \\
\hline Inulin-type & Structure overview & Not applicable & $(172)$ \\
\hline Short-chain carbohydrates & Gut function and health & Human & $(175)$ \\
\hline Inulin-type & Bifidogenic, resistant to digestion & Non-specific & $(176)$ \\
\hline Resistant starch & $\begin{array}{l}\text { Production of SCFA, microbiome modulation, gut-associated } \\
\text { immunomodulation }\end{array}$ & Human & $(177)$ \\
\hline Mannan-oligosaccharides & Modulation of gut microbiome & Poultry & $(27)$ \\
\hline $\begin{array}{l}\text { Fructo-oligosaccharide, galacto- } \\
\text { oligosaccharide, lactulose }\end{array}$ & Criteria for prebiotic classification & Human & $(168)$ \\
\hline Inulin-type, oligofructose & Quantification of inulin and oligofructose in Western diet & Human & $(173)$ \\
\hline Fructo-oligosaccharide & Bifidogenic, lack carcinogenic and toxic effects & Poultry, swine & $(174)$ \\
\hline Fructo-oligosaccharide, inulin-type & Selective to beneficial bacteria, prevent pathogen colonization & Poultry & $(178)$ \\
\hline
\end{tabular}


into the precise definition of prebiotics as set by Roberfroid (22), among other classical definitions. However, they have prebioticlike effects in that they have been shown to enhance nutrient utilization and digestibility, as well as improving the immune system and inhibiting pathogen-intestinal cell interaction by modifying the GIT microbiome (179-181). The fermentation of S. cerevisiae - undefined strains - produces SCFP. They include the fermentation products and metabolites, the media used in the fermentation to preserve fermentation activity, and both the yeast cell wall fragments and residual live yeast cells; thus, they share characteristics in both probiotic and prebiotic realms (179). There are commercial YC products available that are being more thoroughly investigated to identify their exact effects and maximize the directed influence(s) they may have.

Because yeasts are most often associated with the wine making, brewing, baking, and other fermenting industries, it is critical to consider why these unique organisms were initially promoted for use in improvements of animal and human health. In order to do this, a brief review of the history of yeast that led to its usage as a feed additive is discussed in the following section.

\section{Introduction to Yeast: History and Background}

To understand the current use of yeast and yeast products in food and agricultural settings, it is important to at least briefly describe the history of yeast in scientific applications and the evidence for the close relationship among yeast strains originally uncovered and those used in today's laboratory-based research. Humans began using yeast over 7,000 years ago, with its earliest usage dating back to the Neolithic times for wine making $(182,183)$. In the past century, yeasts have been investigated on a genetic level after the Carlsberg Laboratory introduced scientific concepts to the brewing industry, as discussed by Greig and Leu (184). In the 1930 s, the genetic analysis of yeast became accepted based on its potential as an experimental organism; it was pioneered by Øjvind Winge and Carl Lindegren (185). Winge used a strain isolated from the Carlsberg Laboratory, while Lindegren used a strain, EM93, isolated from rotting Californian figs (182). Yeast continued gaining popularity in the scientific field for its ease in gene manipulation (182). In the 1950s, Robert Mortimer constructed the strain S288C, which has been purported to share more than $85 \%$ of its genome with EM93, Lindegren's original strain (most laboratories involved in the analysis of yeast use a derivative of EM93 - a strain of $S$. cerevisiae). This strain was subsequently sequenced in 1996, making it the first fully sequenced yeast genome $(186,187)$. For further purposes of the current review, $S$. cerevisiae is the main species of yeast discussed unless otherwise indicated.

\section{Yeast in the Laboratory}

A renowned model organism, yeast is a single-celled fungal eukaryote that most often divides by budding. Yeasts are used in various industries because of their ability to ferment sugars in the absence of oxygen to produce $\mathrm{CO}_{2}$ and alcohol. In a laboratory setting, yeasts are most often used for analysis as a model template to study higher eukaryotic organisms. Yeasts are ideal for studying processes known to occur in more complex eukaryotic organisms because even though yeasts are unicellular, they encode similar proteins and are thus representative of more complex organisms at the cellular level (188). When comparing all yeast protein sequences to mammalian sequences, of the potential protein encoding regions in yeast, "statistically robust" homology among the two was observed (189). Because of the lack of mammalian protein families and proteins sequenced, there may be much greater similarities between the two.

Part of the attraction of yeast as an experimental model is the ability to easily manipulate and mutate genes, either on plasmids or in the yeast chromosome itself, to view the resulting phenotypic effects (182). An insight into its fairly simple manipulation is evident in research performed by both Caspeta et al. (190) and Liu et al. (191). Caspeta et al. (190) manipulated S. cerevisiae into expressing thermotolerance to temperatures $\geq 34^{\circ} \mathrm{C}$ (typical response to these temperatures is serious impairment of function) by exposing the isolate for short stretches of time to increased heat followed by serial batch transfers. This resulted in non-inheritable heat tolerant strains that exhibited increased growth rates as well as increased glucose consumption rates at higher temperatures when compared to thermolabile strains (190). Thermotolerance has also been bestowed upon $S$. cerevisiae by the introduction of genes from organisms that are naturally thermotolerant. This transfer of genes allows for inheritable alteration in future generations of S. cerevisiae. Duina et al. (182) illustrated the extent to which yeast has proven its efficacy as a model organism, discussing research advancements and accolades (Nobel Prize and Lasker Award) in an array of fields achieved by utilizing yeast.

Although great progress has resulted from the study of yeast, it has also stimulated further inquiry. Yeast researchers began with the goal of determining functions of single genes and proteins, but now seek a "systems level" approach. The benefit of understanding how proteins interact to maintain cellular functions (metabolism, reproduction, growth, regulation, signaling, and homeostasis) is now at the forefront for yeast biology (192). Yeast's position as a model organism for various scientific fields is reviewed more thoroughly in several articles and therefore will not be further discussed here (192-194). A review by Siddiqui et al. (195) encompasses the potential of engineering yeasts to contain secondary metabolite pathways for pharmacological purposes. Additionally, Sherman (196) has generated a comprehensive review (both extended and truncated versions available) on the biological basics of yeast, which includes a section on a variety of outside literature references for yeast.

\section{Yeast Metabolism}

Yeasts are capable of cellular respiration in the presence and absence of oxygen; for this review, we will discuss respiration only in the absence of oxygen, as it is most applicable to the topic of the current review. Anaerobic respiration, or fermentation, is the process of breaking down sugars to generate energy for carrying out cellular processes. In anaerobic cellular respiration, sugars are broken down into pyruvate and subsequently decarboxylated and reduced to form $\mathrm{CO}_{2}$ and ethanol. For fermentation to begin, any complex sugars must be broken down into simple sugars 
(e.g., sucrose to glucose and fructose) via enzymes from yeasts, adding an additional step to the fermentation process (197). In the process of understanding this, it is recognized that complex carbohydrates (starches and fiber) are more challenging for yeasts to ferment than simple sugars. Investigation into the types of sugars and environments yeasts are capable of fermenting is necessary to optimize the production and utilization of yeast fermentation products. By understanding the conditions in which yeast fermentation is optimized, they can be engineered to generate additional metabolites that may prove to be beneficial for use in animal feed.

\section{Yeast as an Animal Feed Additive}

The usage of live yeast and yeast products in animal feed is not a new concept, although pinpointing the exact point of its conception has proven to be challenging. It is suggested that the introduction of YC in animal feed was not until the 1980s (198). It appears that the majority of research has been dedicated toward ruminants, while equine, porcine, poultry, and companion animals received attention to a lesser extent. Initially, yeast was used in an array of modes because of the large quantities of yeast biomass waste generated by distilleries (and other yeast utilizing industries) (199). It was used as a feed additive because it was a rich source of protein, fiber, and minerals. It has been hypothesized that both viable and non-viable yeast cells provide essential B vitamins and organic acids (200). In the past, both viable and non-viable yeast cells have been added to animal feed - including poultry feed - and resulted in increased host growth and improved health (199).

It is essential to have a precise definition for $\mathrm{YC}$, so it is not confused with using live yeast (probiotic/direct fed microbial form) or yeast extract (only soluble portion of yeast autolysis) products (201). As described in a previous section of the current review, YC contains the cellular constituents as well as residual viable cells. It is effective when used because it contains lysed yeast cells; this allows for the nutrients within the yeast cells to be available for digestion and absorption (202). These yeast cells are lysed by autolysis; they are subjected to temperature or osmotic shock, thereby killing the yeast cell while leaving the endogenous enzymes undamaged. The yeast cell's own enzymes begin to degrade the yeast cell, releasing its contents and further degrading its proteins into amino acids (203). Some yeast cells that are capable of tolerating the temperature or osmotic shock, do not autolyze, and remain metabolically active.

The mode of action of $\mathrm{YC}$ is seen to enhance digestive and fermentative functions of the GIT, while modifying activities of the GIT microbiota, although the mechanisms are less clear (198). Based on in vitro and in vivo studies, supplemented YCs appear to have several impacts on the rumen microbiota including increased numbers of beneficial bacteria and fiber digesting bacteria as well as shifting away from hydrogen consuming methanogens and toward bacteria capable of converting hydrogen and $\mathrm{CO}_{2}$ to acetic acid, all of which could, in turn, potentially benefit the ruminant host animal either directly or indirectly $(204,205)$. Enhanced growth performance resulting from the supplementation of YC with probiotics (Lactobacillus acidophilus and Streptococcus faecium) has indicated its potential effect of increasing digestion and absorption of the GIT microbiota occurring in broiler chickens (206). de Oliva Neto et al. (207) conducted studies on the antibacterial properties of YC supernatant, which indicated a reduction of pathogenic bacterial growth when tested against a common distillery bacterial species. Interestingly, the supernatants were tested as both fresh and post freeze/thaw, and reported similar results indicating the antimicrobial activity could withstand freezing. Conversely, when heat $\left(90^{\circ} \mathrm{C}\right.$ for $\left.20 \mathrm{~min}\right)$ was applied, the antibacterial activity was destroyed. Accordingly, YC and yeast extract have yielded varying results, which suggests the necessity for metabolically active yeast cells. When supplementing heat-treated inactive yeast cells to steer diets, there was no effect on the concentrations of cellulolytic bacteria, while supplementing live, metabolically active yeast cells increased the concentration of cellulolytic bacteria (208).

In addition to their ability to interfere with bacteria due to their relative large size, supplementation with live yeast products has led to a few suggested modes of action (209). One mechanism suggested by Jouany et al. (204) involves metabolic competition with bacteria that may be adhering to and digesting fiber or starch molecules. In this scenario, the yeasts ferment the carbohydrates produced, prohibiting their usage by other bacteria. Another mechanism of action of live yeast cells is their ability to produce protective products with antitoxin effects (210). Yeast intake has resulted in a stimulation of activity of host intestinal brush border enzymes, which has counteractive effects to those of pathogens, along with supplying the host with additional enzymes (211). Elimination of oxygen has been deemed the most influential mode of action in ruminants (212). Although there is little oxygen present in the GIT, live yeast cells scavenge for excess oxygen introduced by food and water intake; this allows for a more optimal environment for anaerobic bacteria (204, 212). Most all implications regarding the mechanism of oxygen elimination have been derived from studies conducted on ruminants.

As noted previously, the majority of the studies on the effects and mechanisms of YC have been performed on ruminants. Although such studies may be a good indicator of the potential use of YC in other animals, it can also be expected that there will be differences seen among ruminants and non-ruminants. For example, considerable research has been conducted on the effects of milk production in cattle, while this is beneficial for other lactating animals, the information gleaned from these studies holds little merit for poultry researchers. Instead, conducting in vitro and in vivo studies on specific animal subjects of interest would be more useful in identifying the mechanisms of $\mathrm{YC}$ in those animals rather than projecting ruminant/rumen microbiota results onto non-ruminant species.

\section{Impact of YC on Host-Microorganism Interactions}

The effects of $\mathrm{YC}$ on the intestinal morphology in swine have indicated increased jejunal villi width, which allows for greater digestive and absorptive intestinal capacity leading to better body weight gain when compared to controls (180). In contrast, poultry data obtained has thus far indicated significant differences in intestinal morphology (213-215). Supplementation of YC has resulted in more shallow crypt depths, indicating less necessity for cell renewal and turn-over, allowing for decreased 
host energy utilization for intestinal epithelial maintenance (216). Feed efficiency and body weight gain have both resulted in significant increases when YC, yeast derivatives, and live yeast cells are added to the poultry diet $(215,217,218)$.

Inclusion of YC in animal feed has led to suggestions that they may aid in the clearing of pathogens from infected animals. A study involving the inoculation of pigs with Salmonella suggested that the inclusion of YC in the diet allowed for rapid shedding of the pathogen from the GIT (180). Supplementation of broiler feed with YC has also been seen to enhance adaptive immune system $\mathrm{T}$ lymphocytes, allowing for better clearing of the pathogens (181). El-Husseiny et al. (219) observed that commercial YC were able to significantly increase antibody production against SRBC, much in agreement with the findings of Al-Homidan and Fahmy (220), who reported significantly higher antibody titer concentrations in response to Newcastle disease in broilers fed YC.

Further examination into the components of yeasts' cell walls indicates the beneficial structural polysaccharides present and released into culture when yeast cells autolyze. Mannanoligosaccharide (MOS) is included in the $\mathrm{YC}$ as it is derived from the outer cell wall of $S$. cerevisiae. MOSs bind to pathogenic bacteria in the GIT, preventing their attachment to the mannan residues on intestinal epithelia (221). This not only protects the host from pathogens but also allows for host energy reserves to be utilized for their own growth rather than to the repair and regeneration of the epithelial lining (222). $\beta$-glucans are also released when the yeast cell wall is degraded; presence of these molecules can lead to pathogen inhibition along with immunomodulating effects. Similar to MOS, $\beta$-glucans act by preventing pathogens from binding to the villi of the gut mucosa $(214,216)$. Additionally, $\beta$-glucans are known to activate phagocytes, natural killer cells and B and T lymphocytes as well as increase cytokine production and phagocytic activity of macrophages (223).

Mannan-oligosaccharide supplementation has been reported to increase broiler growth performance when supplemented in their diet $(224,225)$. In vitro experimentation has indicated that addition of MOS inhibits the attachment of enteropathogenic $E$. coli to the gut mucosa as well as removing attached $E$. coli from the mucosa (226). Inclusion of yeast fermentation products, like MOS, appears to reduce pathogenic bacterial populations. The mechanism is unclear, although the agglutination of the pathogens with sugars from the yeast cell wall occurs rather than attachment to the host intestinal lining is one hypothesized mechanism (227). Yang et al. (228) indicated MOS altered the gut microbiota of broilers and reduced the number of mucosal-associated coliforms.

Although some studies suggest a positive association between yeast and growth promotion $(229,230)$, other studies have indicated no positive effects on inclusion of YC in broiler diets (231). Paryad and Mahmoudi (229) indicated that inclusion of $2 \%$ yeast (Saccharomyces cerevisae) in broiler chicken diets resulted in significant differences in body weight gain, feed intake, and feed conversion rate when compared to controls. Similarly, investigation into $\mathrm{YC}$ on growth promotion in lambs suggested its efficacy, resulting in increased feed intake and growth by 8 and 26\%, respectively. Conversely, similar research conducted on lambs evaluating the efficacy of three yeast strains and a mixed culture resulted in little consistency and lacked an overall effect when compared among yeast strains (232). Adebiyi et al. (231) also showed no significant differences in body weight gain in broiler chickens when fed varying percentages of YC.

\section{Yeast Metabolites and Metabolism as Prebiotic-Like Substances}

In addition to the structural polysaccharides derived from the yeast cell wall, yeasts generate a number of metabolites that may offer benefits to the host animal when supplemented to animal feed. Metabolites include carotenoids, vitamins, enzymes, amino acids, and some miscellaneous products (200). Several yeast species are naturally capable of producing carotenoids (including $\beta$-carotenes), which are subsequently metabolized into vitamin A (200). Vitamin A aids in cellular differentiation and proliferation, making it critical for intestinal maintenance and health (233). The enzyme responsible for the synthesis of vitamin A from $\beta$-carotene is $\beta, \beta$-carotene $15,15^{\prime}$-monooxygenase, which has been isolated and characterized from the intestines of poultry, among other animals $(234,235)$. Although S. cerevisiae is not capable of naturally producing carotenoids, it is capable of and has been engineered to express a biosynthetic pathway for the production of $\beta$-carotene (236).

Other vitamins (vitamin precursors) produced by yeasts include ergosterol, L-ascorbic acid, and D-erythroascorbic acid. Ergosterol is particularly abundant in S. cerevisiae, accounting for up to $90 \%$ of the total sterols (237). It is located in the membrane of yeasts and is responsible for its fluidity, structure, permeability, and activity of membrane-bound enzymes (238). Ergosterol is a precursor to both vitamin $\mathrm{D}_{2}$ and cortisone (239). Vitamin $\mathrm{D}_{2}$ is responsible for the proper absorption and transport of calcium, among other minerals (240). D-Erythroascorbic acid is also synthesized by $S$. cerevisiae and depending on the substrates available, that pathway can be manipulated into producing $\mathrm{L}$-ascorbic acid (vitamin C) (241). The ingestion of vitamin C has been suggested to alleviate some of the repercussions of heat stress: poor immune function and growth performance (242). However, instances of supplementation of L-ascorbic acid in poultry diets have had varying results; some resulted in increased levels of superoxide dismutase in 45-week-old broilers, while others revealed no effect on the activities of antioxidative enzymes, superoxide dismutase included in 7-week-old broilers $(243,244)$.

Yeasts are recognized for their production of enzymes expressing various activities (245). Jones (246) wrote a comprehensive review documenting the activities of the proteolytic systems in $S$. cerevisiae, along with mentioning other enzymes elucidated in $S$. cerevisiae (carboxypeptidases, aminopeptidases, and dipeptidyl aminopeptidases). An enzyme in Saccharomyces boulardii, a subtype of $S$. cerevisiae, was found to degrade the ileal receptors in rats for toxin A generated from Clostridium difficile (a foodassociated pathogen causing gastroenteritis; one study isolated C. difficile from $2.3 \%$ of broiler chickens tested) $(247,248)$. The degradation of the receptors prohibits the toxin from binding and prevents infection from occurring $(249,250)$. There have been multiple other proposed mechanisms of action for yeast on the immunoprotective effect in the GIT, specifically the prevention of C. difficile infection: (1) S. boulardii releases proteases that hydrolyze toxins and prevent its binding to the intestinal receptor (250), 
(2) S. boulardii is capable of stimulating the activity of disaccharidases in the intestinal brush border with no additional alterations of the intestinal mucosa (211), and (3) S. boulardii increased the production and secretion of glycoproteins, namely the secretory component of immunoglobulin A (251). Potentially, by narrowing the focus on the exact mechanism of action, $S$. cerevisiae could be engineered to confer said mechanism and supplemented into animal (poultry) feed to prevent colonization of C. difficile.

Invertase is another enzyme produced by $S$. cerevisiae; it hydrolyzes sucrose into glucose and fructose (252). Invertase efficiency and sucrose availability allows for glucose to be a carbon source for S. cerevisiae (252). Ideally, provided the diet contained appropriate levels of sucrose, one could engineer $S$. cerevisiae to overproduce invertase and subsequently add it to poultry feed. This would allow increased production of glucose, available not only for its own needs but also for other microorganisms in the surrounding environment. This mode of action would not be selective toward beneficial bacteria in the microbiome.

Yeasts have multiple amino acid transport systems; amino acids are incorporated into proteins or they are broken down and utilized as nitrogen and carbon sources to promote growth (253). Yeasts and yeast derivatives are capable of producing amino acids; therefore supplementation to animal feed would provide both the host and the microbiome with amino acids. Almquist (254) reviewed the essential amino acid requirements in young chicks, laying hens, and turkeys; Almquist included a table outlining the percentages of each amino acid to reach a specific protein level. Amino acids are necessary for poultry to have proper growth and promote efficient weight gain and feed conversion ratios (255). Lysine appears to be one such amino acid that plays a significant role in the body composition of poultry (256). Mutants of $S$. cerevisiae have been revealed to produce up to 17 times as much lysine as wildtype; thus this rich source of lysine may prove to be valuable to the growth and development of poultry (257).

Miscellaneous metabolites are also produced in S. cerevisiae, including toxins responsible for the "killer phenomenon." Originally, this phenomenon was considered to be lethal only toward members of the same species; however, further investigation has led to the recognition of these toxic species to have destructive consequences reaching both prokaryotic and eukaryotic organisms (258-261). Polonelli and Morace (261) acknowledge that the inhibition of outside species may not be a direct impact on the toxins secreted, but more of a concerted effort from multiple metabolites. Nevertheless, these toxic species of $S$. cerevisiae are displaying lethality toward unrelated species. This can be utilized to the advantage of commercial poultry production, provided further research is conducted on characterizing whether this toxicity also occurs toward beneficial bacteria.

\section{Conclusions: Impact on Poultry Industry and Future Directions}

In the search for a replacement to antibiotic growth promoters, the poultry broiler industry has two main objectives, a substance that (1) increases the growth of broiler chickens (body weight gain and feed conversion ratio) and (2) prevents the colonization of invading pathogens. Ideally, a single feed additive would prevent pathogen colonization while developing beneficial microbiota to aid in bird growth and feed conversion (262). Multiple feed additives have been attempted: antimicrobial agents, probiotics, prebiotics, and prebiotic-like substances. Probiotics need to be clearly identified and carefully analyzed to understand the influence they may have on the poultry GIT microbiota. As discussed previously, lactobacilli and bifidobacteria are two known groups that provide the host health and well-being based on their end products. These bacteria both ward off pathogens by creating an unfavorable environment against pathogen retention in the gut and also generally aid host GIT health, in turn resulting in enhanced bird growth (133).

To increase the efficacy of supplying probiotics to the host, the concept of synbiotics has been suggested. Synbiotics entail equipping the beneficial bacteria with substrates specific to their metabolic needs (23). Potentially, this allows for the greatest impact as it reduces the substrates taken by the probiotics from the host. Prebiotic-like substances are often times non-selective, therefore, combining a probiotic and a prebiotic-like substance does not fit into the synbiotic definition (263). Understanding the effects and specificity of probiotics, prebiotics, and prebiotic-like substances will allow for the best match of known commensal bacterial communities and substrates for a given host.

Yeast cells and YC products developed thus far have been extensively examined for their effects as supplements in animal feed. Numerous studies report the positive association with growth performance, immunostimulation, and microbiome modulation in animals and humans (209). In addition to being explored for their positive impacts as supplements in animal feed, yeasts and their derivatives have been investigated for their low risk and assurances of safety in their usage. Yeasts are cost efficient in both production and formulation (200). They do not have the ability to transfer genes they may acquire to pathogenic or commensal bacteria, or to the host. Yeasts are able to resist acquisition of antimicrobial resistance as well as not allowing for the transfer of such resistance (209). This also allows yeast to be safely used in parallel with antibacterial agents. Yeasts also have multiple mechanisms of action, allowing them to be productive in a range of environments (200).

A more thorough understanding of the microbiome can elucidate the mechanisms of prebiotics and prebiotic-like substances. The GIT microbiome is distinct and unique in its functionality relying on the presence of a definable, and potentially identifiable, microbial consortia. Understanding the influences of the members of the microbiome and also the microbiome as a single entity will allow for a more directed approach in the search of therapeutics and growth promoters. The GIT microbiome may be more appropriately considered as an additional organ; it has impact on host growth and development, and host health.

The limitations in previous research conducted have made future research necessary to resolve unanswered questions. It is imperative to define universal and standardized detection methodology to identify the bacterial communities present in the healthy, mature poultry microbiome. This would alleviate the issue of having varying results based on detection methods utilized. In addition, evaluating the currently suggested probiotic candidate organisms (Table 3 ) indicates the potential advantages of involving multiple potential probiotic bacterial and yeast strains to exhibit 
a concerted effort in maintaining GIT health. This would allow for the identification of potentially more uniform mixed probiotic cultures consisting of functionally well-defined individual bacterial members that when used to inoculate newly hatched chicks ensures more rapid development of a mature beneficial microbiome.

Further work with yeast, YC, and yeast extracts needs to be conducted on poultry. Much of the discussion in the current review was based on the results from yeast products applied to animals and humans but not poultry. To gain an accurate sense of the effects in poultry, such experimentation needs to be conducted in poultry (in vitro and in vivo). Additionally, many of the metabolites mentioned previously were investigated independent of yeast, YC, or yeast extract. It would be beneficial to assess the impact of metabolites and components from yeast individually as well as when combined. This would allow for the identification

\section{References}

1. US EPA. Background of Poultry Production. Poultry Production Ag 101 (2013) [cited 2015 Aug 24]. Available from: http://www.epa.gov/oecaagct/ag101/ poultry.html

2. Daniel CR, Cross AJ, Koebnick C, Sinha R. Trends in meat consumption in the USA. Public Health Nutr (2010) 14:575-83. doi:10.1017/ S1368980010002077

3. USDA Office of Communications. Ch 2: profiling food consumption in America. Agriculture Fact Book 2001-2002. Washington, DC (2003) [cited 2015 Aug 24]. Available from: http://www.usda.gov/factbook/chapter2.pdf

4. Emmerson DA. Commercial approaches to genetic selection for growth and feed conversion in domestic poultry. Poult Sci (1997) 76:1121-5. doi:10.1093/ $\mathrm{ps} / 76.8 .1121$

5. Cherry JA, Siegel PB, Beane WL. Genetic-nutritional relationships in growth and carcass characteristics of broiler chickens. Poult Sci (1978) 57:1482-7. doi: $10.3382 /$ ps. 0571482

6. Lumpkins BS, Batal AB, Lee MD. Evaluation of the bacterial community and intestinal development of different genetic lines of chickens. Poult Sci (2010) 89:1614-21. doi:10.3382/ps.2010-00747

7. de Verdal H, Narcy A, Bastianelli D, Chapuis H, Meme N, Urvoix S, et al. Improving the efficiency of feed utilization in poultry by selection. 2 . Genetic parameters of excretion traits and correlations with anatomy of the gastro-intestinal tract and digestive efficiency. BMC Genet (2011) 12:71. doi:10.1186/1471-2156-12-71

8. Norris D, Ngambi JW. Genetic parameters estimates for body weight in local Venda chickens. Trop Anim Health Prod (2006) 38:605-9. doi:10.1007/ s11250-006-4420-6

9. Leeson S, Caston L, Summer JD. Layer performances of four strains of Leghorn pullets subjected to various rearing programs. Poult Sci (1997) 76:1-5. doi:10.1093/ps/76.1.1

10. Havenstein GB, Ferket PR, Scheideler SE, Rives DV. Carcass composition and yield of 1991 vs 1957 broilers when fed "typical" 1957 and 1991 broiler diets. Poult Sci (1994) 73:1795-804. doi:10.3382/ps.0731795

11. Havenstein GB, Ferket PR, Qureshi MA. Growth, livability, and feed conversion of 1957 versus 2001 broilers when fed representative 1957 and 2001 broiler diets. Poult Sci (2003) 82:1500-8. doi:10.1093/ps/82.10.1500

12. Ravindran A. FAO Poultry Development Review. Poultry Feed Availability and Nutrition in Developing Countries: Main Ingradients Used in Poultry Feed Formulations. (2013) [cited 2015 Aug 24]. Available from: http://www. fao.org/docrep/019/i353ie.pdf

13. Bunyan J, Jeffries L, Sayers JR, Gulliver AL, Coleman K. Antimicrobial substances and chick growth promotion: the growth-promoting activities of antimicrobial substances, including fifty-two used either in therapy or as dietary additives. Br Poult Sci (1977) 18:283-94. doi:10.1080/00071667708416364

14. Feighner SD, Dashkevicz MP. Subtherapeutic levels of antibiotics in poultry feeds and their effects on weight gain, feed efficiency, and bacterial cholyltaurine hydrolase activity. Appl Environ Microbiol (1987) 53:331-6. of beneficial metabolites and their respective individual and combined functional impacts on the corresponding host.

\section{Funding}

Funding is provided internally by Dr. Steven Ricke's lab.

\section{Acknowledgments}

We thank the University of Arkansas, Fayetteville, Department of Food Science program for supporting SR with a graduate student assistantship. We would also like to acknowledge Dr. Jeffrey Lewis, Department of Biological Sciences, University of Arkansas, Fayetteville, AR, USA for his input on yeast biology.

15. Gaskins HR, Collier CT, Anderson DB. Antibiotics as growth promotants: mode of action. Anim Biotechnol (2002) 13:29-42. doi:10.1081/ ABIO-120005768

16. Dibner JJ, Richards JD. Antibiotic growth promoters in agriculture: history and mode of action. Poult Sci (2005) 84:634-43. doi:10.1093/ps/84.4.634

17. Jones FT, Ricke SC. Observations on the history of the development of antimicrobials and their use in poultry feeds. Poult Sci (2003) 82:613-7. doi:10.1093/ps/82.4.613

18. HHS. National Action Plan for Combating Antibiotic-Resistant Bacteria. Washington, DC: Presidential Advisory Council on Combating AntibioticResistant Bacteria (2015).

19. Castanon JIR. History of the use of antibiotic as growth promoters in European poultry feeds. Poult Sci (2007) 86:2466-71. doi:10.3382/ps.2007-00249

20. CDC. Antibiotic Resistance Threats in the United States, 2013. Altanta, GA: Center for Disease Control and Prevention (2013) [cited 2015 Aug 24] Available from: http://www.cdc.gov/drugresistance/pdf/ar-threats-2013-508. pdf

21. Huyghebaert G, Ducatelle R, Van Immerseel F. An update on alternatives to antimicrobial growth promoters for broilers. Vet $J$ (2011) 187:182-8. doi:10.1016/j.tvjl.2010.03.003

22. Roberfroid MB. Prebiotics: the concept revisisted. J Nutr (2007) 137:830S-7S.

23. Patterson JA, Burkholder KM. Application of prebiotics and probiotics in poultry production. Poult Sci (2003) 82:627-31. doi:10.1093/ps/82.4.627

24. Flickinger EA, Van Loo J, Fahey GC Jr. Nutritional responses to the presence of inulin and oligofructose in the diets of domesticated animals: a review. Crit Rev Food Sci Nutr (2003) 43:19-60. doi:10.1080/10408690390826446

25. Lutful Kabir SM. The role of probiotics in the poultry industry. Int J Mol Sci (2009) 10:3531-46. doi:10.3390/ijims10083531

26. Fuller R. Probiotics in man and animals. J Appl Bacteriol (1989) 66:365-78. doi:10.1111/j.1365-2672.1989.tb05105.x

27. Yang Y, Iji PA, Choct M. Dietary modulation of gut microflora in broiler chickens: a review of the role of six kinds of alternatives to in-feed antibiotics. Worlds Poult Sci J (2009) 65:97-114. doi:10.1017/S0043933909000087

28. Ferket PR, Parks CW, Grimes JL. Benefits of Dietary Antibiotic and Mannanoligosaccharide Supplementation for Poultry (2002). Available from: http://www.feedinfo.com/files/multi2002-ferket.pdf

29. Flickinger EA, Fahey GC Jr. Pet food and feed applications of inulin, oligofructose and other oligosaccharides. Br J Nutr (2002) 87:S297-300. doi:10.1079/BJN/2002552

30. Russell JB. Another explanation for the toxicity of fermentation acids at low pH: anion accumulation versus uncoupling. J Appl Bacteriol (1992) 73:363-70. doi:10.1111/j.1365-2672.1992.tb04990.x

31. Ricke SC. Perspectives on the use of organic acids and short chain fatty acids as antimicrobials. Poult Sci (2003) 82:632-9. doi:10.1093/ps/82.4.632

32. Van Immerseel F, Russell JB, Flythe MD, Gantois I, Timbermont L, Pasmans F, et al. The use of organic acids to combat Salmonella in poultry: a mechanistic explanation of the efficacy. Avian Pathol (2006) 35:182-8. doi:10.1080/03079450600711045 
33. Thompson JL, Hinton M. Antibacterial activity of formic and propionic acids in diet of hens on salmonellas in the crop. Br Poult Sci (1997) 38:59-65. doi:10.1080/00071669708417941

34. Ganguly S. Supplementation of prebiotics, probiotics and acids on immunity in poultry feed: a brief review. Worlds Poult Sci J (2013) 69:639-48. doi:10.1017/S0043933913000640

35. Gibson GR, Roberfroid MB. Dietary modulation of the human colonic microbiota: introducing the concept of prebiotics. J Nutr (1995) 125:1401-12.

36. AAM. Human Microbiome FAQ. Washington, DC: American Academy of Microbiology of American Society for Microbiology (2013).

37. Bäckhed F, Ley RE, Sonnenburg JL, Peterson DA, Gordon JL. Host-bacterial mutualism in the human intestine. Science (2005) 307:1915-20. doi:10.1126/ science. 1104816

38. Xu J, Gordon JI. Honor thy symbionts. Proc Natl Acad Sci U S A (2003) 100:10452-9. doi:10.1073/pnas.1734063100

39. Farthing MJ. Bugs and the gut: an unstable marriage. Best Pract Res Clin Gastroenterol (2004) 18:233-9. doi:10.1016/j.bpg.2003.11.001

40. Hall-Stoodley L, Costerton JW, Stoodley P. Bacterial biofilms: from the natural environment to infectious diseases. Nat Rev Microbiol (2004) 2:95-108. doi:10.1038/nrmicro821

41. Aas JA, Paster BJ, Stokes LN, Olsen I, Dewhirst FE. Defining the normal bacterial flora of the oral cavity. J Clin Microbiol (2005) 43:5721-32. doi:10.1128/ JCM.43.11.5721-5732.2005

42. Costello E, Lauber CL, Hamady M, Fierer N, Gordon JI, Knight R. Bacterial community variation in human body habitats across space and time. Science (2009) 326:1694-7. doi:10.1126/science.1177486

43. Han MK, Huang YJ, Lipuma JJ, Boushey HA, Boucher RC, Cookson WO, et al. Significance of the microbiome in obstructive lung disease. Thorax (2012) 67:456-63. doi:10.1136/thoraxjnl-2011-201183

44. Huang YJ, Lunch SV. The emerging relationship between the airway microbiota and chronic respiratory disease: clinical implications. Expert Rev Respir Med (2011) 5:809-21. doi:10.1586/ers.11.76

45. Gill SR, Pop M, DeBoy RT, Eckburg PB, Turnbaugh PJ, Samuel BS, et al. Metagenomic analysis of the human distal gut microbiome. Science (2006) 312:1355-9. doi:10.1126/science.1124234

46. Apajalahti JHA, Kettunen A, Graham H. Characteristics of the gastrointestinal microbial communities, with special reference to chicken. Worlds Poult Sci J (2004) 60:223-32. doi:10.1079/WPS200415

47. Egert M, De Graaf AA, Smidt H, De Vos WM, Venema K. Beyond diversity: functional microbiomics of the human colon. Trends Microbiol (2006) 14:86-91. doi:10.1016/j.tim.2005.12.007

48. Hoffmann C, Hill DA, Minkah N, Kirn T, Troy A, Artis D, et al. Communitywide response of the gut microbiota to enteropathogenic Citrobacter rodentium infection revealed by deep sequencing. Infect Immun (2009) 77:4668-78. doi:10.1128/IAI.00493-09

49. Brisbin JT, Gong J, Sharif S. Interactions between commensal bacteria and the gut-associated immune system of the chicken. Anim Health Res Rev (2008) 9:101-10. doi:10.1017/S146625230800145X

50. Delzenne NM, Cani PD. Interaction between obesity and the gut microbiota: relevance in nutrition. Annu Rev Nutr (2011) 31:15-31. doi:10.1146/ annurev-nutr-072610-145146

51. Munyaka PM, Khafipour E, Ghia J. External influence of early childhood establishment of gut microbiota and subsequent health implications. Front Pediatr (2014) 2:109. doi:10.3389/fped.2014.00109

52. Arrieta M, Stiemsma LT, Amenyogbe N, Brown EM, Finlay B. The intestinal microbiome in early life: health and disease. Front Immunol (2014) 5:427. doi:10.3389/fimmu.2014.00427

53. Mabelebele M, Alabi OJ, Ng’ambi JW, Norris D, Ginindza MM. Comparison of gastrointestinal tracts and $\mathrm{pH}$ values of digestive organs of Ross 308 broiler and indigenous Venda chickens fed the same diet. Asian J Anim Vet Adv (2014) 9:71-6. doi:10.3923/ajava.2014.71.76

54. Pan D, Yu Z. Intestinal microbiome of poultry and its interaction with host and diet. Gut Microbes (2014) 5:108-19. doi:10.4161/gmic.26945

55. Scanes CG, Brant G, Ensminger ME. Poultry biology. 4th ed. Poultry Science. Upper Saddle River, NJ: Prentice Hall (2004). p. 22-45.

56. Duke GE, Petrides GA, Ringer RK. Chromium-51 in food metabolizability and passage rate studies with the ring-necked Pheasant. Poult Sci (1968) 47:1356-64. doi:10.3382/ps.0471356
57. Clarke PL. Coccidial infection with Eimeria tenella and caecal defaecation in chicks. Br Poult Sci (1979) 20:317-22. doi:10.1080/00071667908416586

58. Turk DE. The anatomy of the avian digestive tract as related to feed utilization. Poult Sci (1982) 61:1225-44. doi:10.3382/ps.0611225

59. Gelis S. Evaluating and treating the gastrointestinal system. Clin Avian Med (2013) 1:411-40.

60. Izat AL, Colberg M, Reiber MA, Adams MH, Skinner JT, Cabel MC, et al. Effects of different antibiotics on performance, processing characteristics and parts yield of broiler chickens. Poult Sci (1990) 69:1787-91. doi:10.3382/ ps.0691787

61. Jukes HG, Hill DC, Branion HD. Effect of feeding antibiotics on the intestinal tract of the chick. Poult Sci (1956) 35:716-23. doi:10.3382/ps.0350716

62. Henry PR, Ammerman CB, Campbell DR, Miles RD. Effect of antibiotics on tissue trace mineral concentration and intestinal tract weight of broiler chicks. Poult Sci (1987) 66:1014-8. doi:10.3382/ps.0661014

63. Jacob J. Avian Digestive System [Internet]. Extension America's Research-Based Learning Network (2015) [cited 2015 Apr 14]. Available from: http://www. extension.org:80/pages/65376/avian-digestive-system

64. Zhu XT, Zhong T, Pandya Y, Joerger RD. 16S rRNA-based analysis of microbiota from the cecum of broiler chickens. Appl Environ Microbiol (2002) 68:124-37. doi:10.1128/AEM.68.1.124-137.2002

65. Lan PTN, Hayashie H, Sakamoto M, Benno Y. Phylogenetic analysis of cecal microbiota in chicken by the use of $16 \mathrm{~S}$ rDNA clone libraries. Microbiol Immunol (2002) 46:371-82. doi:10.1111/j.1348-0421.2002.tb02709.x

66. Apajalahti JHA, Kettunen A, Bedford MR, Holben WE. Percent G+C profiling accurately reveals diet-related difference in the gastrointestinal microbial community of broiler chickens. Appl Environ Microbiol (2001) 67:5656-67. doi:10.1128/AEM.67.12.5656-5667.2001

67. Gong J, Forster RJ, Yu H, Chambers JR, Wheatcroft R, Sabour PM, et al. Molecular analysis of bacterial populations in the ileum of broiler chickens and comparison with bacteria in the cecum. FEMS Microbiol Ecol (2002) 41:171-9. doi:10.1111/j.1574-6941.2002.tb00978.x

68. Rada V, Sirotek K, Petr J. Evaluation of selective media for bifidobacteria in poultry and rabbit caecal samples. Zentralbl Veterinarmed B (1999) 46:369-73. doi:10.1046/j.1439-0450.1999.00241.x

69. Malmuthuge N, Li M, Chen Y, Fried P, Griebel PJ, Bushansingh B, et al. Distinct commensal bacteria associated with ingest and mucosal epithelium in the gastrointestinal tract of calves and chickens. FEMS Microbiol Ecol (2012) 79:337-47. doi:10.1111/j.1574-6941.2011.01220.x

70. Apajalahti JHA, Sarkilahti LK, Maki BRE, Heikkinen JP, Nurminen PH, Holben WE. Effective recovery of bacterial DNA and percent-guanine-plus-cytosine-based analysis of community structure in the gastrointestinal tract of broiler chickens. Appl Environ Microbiol (1998) 64:4084-8.

71. Amit-Romach E, Sklan D, Uni Z. Microflora ecology of the chicken intestine using 16S ribosomal DNA primers. Poult Sci (2004) 83:1093-8. doi:10.1093/ ps/83.7.1093

72. Bjerrum L, Enberg RM, Leser TD, Jensen BB, Finster K, Pedersen K. Microbial community composition of the ileum and cecum of broiler chickens as revealed by molecular and culture-based techniques. Poult Sci (2006) 85:1151-64. doi:10.1093/ps/85.7.1151

73. Olsen KN, Henriksen M, Bisgaard M, Nielsen OL, Christensen H. Investigation of chicken intestinal bacterial communities by $16 \mathrm{~S}$ rRNA targeted fluorescence in situ hybridization. Antonie Van Leeuwenhoek (2008) 94:423-37. doi:10.1007/s10482-008-9260-0

74. Collado MC, Sanz Y. Characterization of the gastrointestinal mucosa-associated microbiota of pigs and chickens using culture-based and molecular methodologies. J Food Prot (2007) 70:2799-804.

75. Lu J, Idris U, Harmon B, Hofacre C, Mauer JJ, Lee MD. Diversity and succession of the intestinal bacterial community of the maturing broiler chicken. Appl Environ Microbiol (2003) 69:6816-24. doi:10.1128/ AEM.69.11.6818-6824.2003

76. Mead GC, Adams BW. Some observations on the caecal microflora of the chick during the first two weeks of life. Br Poult Sci (1975) 16:169-76. doi:10.1080/00071667508416174

77. Karunasena E, McMahon KW, Chang D, Brashears MM. Responses to the pathogen Mycobacterium avium subsp. paratuberculosis and beneficial microbes exhibit host sex specificity. Appl Environ Microbiol (2014) 80:4481-90. doi:10.1128/AEM.01229-14 
78. Van der Wielen PW, Keuzenkamp DA, Lipman LJA, van Knapen F, Biesterveld S. Spatial and temporal variation of the intestinal bacterial community in commercially raised broiler chickens during growth. Microb Ecol (2002) 44:286-93. doi:10.1007/s00248-002-2015-y

79. Patterson JA. The commensal microbiota. In: Callaway TR, Ricke SC, editors. Direct-Fed Microbials and Prebiotics for Animals. New York, NY: Springer Science+Business Media, LLC (2011). p. 3-11.

80. Gabriel I, Lessire M, Mallet SG, Guillot JF. Microflora of the digestive tract: critical factors and consequences for poultry. Worlds Poult Sci J (2006) 62:499-512. doi:10.1017/S0043933906001115

81. Lei F, Yin Y, Wang Y, Deng B, Yu HD, Li L, et al. Higher-level production of volatile fatty acids in vitro by chicken gut microbiotas than by human gut microbiotas as determined by functional analyses. Appl Environ Microbiol (2012) 78:5763-72. doi:10.1128/AEM.00327-12

82. McBride BW, Kelly JM. Energy cost of absorption and metabolism in the ruminant gastrointestinal tract and liver: a review. J Anim Sci (1990) 68:2997-3010.

83. Hedge SN, Roll BA, Coates ME. The effects of gut microflora and dietary fibre on energy utilization by the chick. Br J Nutr (1982) 48:73-80. doi:10.1079/ BJN19820089

84. Lan Y, Verstegen M, Tammings S, Williams B. The role of the commensal gut microbial community in broiler chickens. Worlds Poult Sci J (2005) 61:95-104. doi:10.1079/WPS200445

85. Annison EF, Hill KJ, Kenworthy R. Volatile fatty acids in the digestive tract of the fowl. Br J Nutr (1968) 22:207-16. doi:10.1079/BJN19680026

86. Bolton W, Dewar WA. The digestibility of acetic, propionic and butyric acids by the fowl. Br Poult Sci (1965) 6:103-5. doi:10.1080/00071666508415562

87. Muramatsu T, Kodama H, Morishita T, Furuse M, Okumura J. Effect of intestinal microflora on digestible energy and fiber digestibility in chickens fed a high fiber diet. Am J Vet Res (1991) 52:1178-81.

88. Muramatsu T, Nakajima S, Furuse M, Tasaki I, Okumura J. Influence of the gut microflora on fasting heat production in chicks. Br Poult Sci (1988) 29:301-9. doi:10.1080/00071668808417055

89. Muramatsu T, Nakajima S, Okumura J. Modification of energy metabolism by the presence of the gut microflora in the chicken. Br J Nutr (1994) 71:709-17. doi:10.1079/BJN19940178

90. Choct M. Soluble non-starch polysaccharides affect net utilization of energy by chickens. Rec Adv Anim Nutr Aust (1999) 12:31-5.

91. Gaskins HR. Immunological development and mucosal defense in the pig intestine in progress. In: Wiseman J, Varley MA, Chadwick JP, editors. Progress in Pig Science. Nottingham: Nottingham University Press (1998). p. 81-101.

92. Furuse M, Yokota H. Protein and energy utilization in germ-free and conventional chicks given diets containing different levels of dietary protein. $\mathrm{Br}$ J Nutr (1984) 51:255-64. doi:10.1079/BJN19840030

93. Hardin G. The competitive exclusion principle. Science (1960) 131:1292-7. doi:10.1126/science.131.3409.1292

94. Lawley TD, Walker AW. Intestinal colonization resistance. Immunology (2012) 138:1-11. doi:10.1111/j.1365-2567.2012.03616.x

95. Crhanova M, Hradecka H, Faldynova M, Matulova M, Havlickova H, Sisak F, et al. Immune response of chicken gut to natural colonization by gut microflora and to Salmonella enterica serovar enteritidis infection. Infect Immun (2011) 79:2755-63. doi:10.1128/IAI.01375-10

96. Al-Zenki SF, Al-Nasser AY, Al-Saffar AE, Abdullah FK, Al-Bahouh ME, Al-Haddad AS, et al. Effects of using a chicken-origin competitive exclusion culture and probiotic cultures on reducing Salmonella in broilers. J Appl Poult Res (2009) 18:23-9. doi:10.3382/japr.2008-00036

97. Nurmi E, Rantala M. New aspects of Salmonella infection in broiler production. Nature (1973) 241:210-1. doi:10.1038/241210a0

98. Gleeson TM, Stravic S, Blanchfield B. Protection of chicks against Salmonella infection with a mixture of pure culture of intestinal bacteria. Avian Dis (1989) 33:636-42. doi:10.2307/1591137

99. Nisbet D. Defined competitive exclusion cultures in the prevention of enteropathogen colonization in poultry and swine. Antonie Van Leeuwenhoek (2002) 81:481-6. doi:10.1023/A:1020541603877

100. Lloyd AB, Cummings RB, Kent RD. Prevention of Salmonella typhimurium infection in poultry by pre-treatment of chickens and poults with intestinal extracts. Aust Vet J (1997) 53:82-7. doi:10.1111/j.1751-0813.1977.tb14891.x
101. Barnes EM, Impey CS, Cooper DM. Manipulation of the crop and intestinal flora of the crop and intestinal flora of the newly-hatched chick. Am J Clin Nutr (1980) 33:2426-33.

102. Corrier DE, Hinton A, Ziprin RL, Beier RC, DeLoach JR. Effect of dietary lactose on cecal $\mathrm{pH}$, bacteriostatic volatile fatty acids, and Salmonella typhimurium colonization of broiler chicks. Avian Dis (1990) 34:617-25. doi: $10.2307 / 1591254$

103. Stavric S. Defined cultures and prospects. Int J Food Microbiol (1992) 15:245-63. doi:10.1016/0168-1605(92)90056-9

104. Schleifer JH. A review of the efficacy and mechanism of competitive exclusion for the control of Salmonella in poultry. Worlds Poult Sci J (1985) 41:72-83. doi:10.1079/WPS19850007

105. Mead GC. Prospects for 'competitive exclusion' treatment to control salmonellas and other foodborne pathogens in poultry. Vet $J$ (2000) 159:111-23. doi:10.1053/tvjl.1999.0423

106. Stavric S, D’Aoust JY. Undefined and defined bacterial preparations for the competitive exclusion of Salmonella in poultry - a review. J Food Prot (1993) 56:173-80.

107. Paul B, Hirshfield I. The effect of acid treatment on survival and protein expression of a laboratory K-12 strain Escherichia coli. Res Microbiol (2003) 154:115-21. doi:10.1016/S0923-2508(02)00011-6

108. Levison ME. Effect of colon flora and short-chain fatty acids on growth in vitro of Pseudomonas aeruginosa and Enterobacteriaceae. Infect Immun (1973) 8:30-5.

109. Lee A, Gemmell E. Changes in the mouse intestinal mictoflora during weaning: role of volatile fatty acids. Infect Immun (1972) 5:1-7.

110. Mani-López E, García HS, López-Malo A. Organic acids as antimicrobials to control Salmonella in meat and poultry products. Food Res Int (2012) 45:713-21. doi:10.1016/j.foodres.2011.04.043

111. Cherrington CA, Hinton M, Mead GC, Chopra I. Organic acids: chemistry, antibacterial activity and practical applications. Adv Microb Phys (1991) 32:88-108. doi:10.1016/S0065-2911(08)60006-5

112. Davidson PM, Taylor TM, Schmidt SE. Chemical preservatives and natural antimicrobial compounds. In: Doyle MP, editor. Food Microbiology: Fundamentals and Frontiers. Washington, DC: ASM Press (2007). p. 765-801.

113. Cherrington CA, Hinton M, Chopra I. Effect of short-chain organic acids on macromolecular synthesis in Escherichia coli. J Appl Bacteriol (1990) 68:69-74. doi:10.1111/j.1365-2672.1990.tb02550.x

114. Axe DD, Bailey JE. Transport of lactate and acetate through the energized cytoplasmic membrane of Escherichia coli. Biotechnol Bioeng (1995) 47:8-19. doi:10.1002/bit.260470103

115. Kashket ER. Bioenergetics of lactic acid bacteria: cytoplasmic $\mathrm{pH}$ and osmotolerance. FEMS Microbiol Lett (1987) 46:233-44. doi:10.111 1/j.1574-6968.1987.tb02463

116. Diez-Gonzalez F, Russell JB. Effects of carbonylcyanide- $m$-chlorophenylhydrazone (CCCP) and acetate on Escherichia coli O157:H7 and K-12: uncoupling versus anion accumulation. FEMS Microbiol Lett (1997) 151:71-6. doi: 10.1111/j.1574-6968.1997.tb10396.x

117. Alakomi H-L, Skyttä E, Saarela M, Mattila-Sandholm T, Latva-Kala K, Helander IM. Lactic acid permeabilizes Gram-negative bacteria by disrupting the outer membrane. Appl Environ Microbiol (2000) 66:2001-5. doi:10.1128/ AEM.66.5.2001-2005.2000

118. Alakomi H-L, Puupponen-Pimiä R, Aura A-M, Helander IM, Nohynek L, Oksman-Caldentey K-M, et al. Weakening of Salmonella with selected microbial metabolites of berry-derived phenolic compounds and organic acids. J Agric Food Chem (2007) 55:3905-12. doi:10.1021/jf070190y

119. Kwon YM, Ricke SC. Induction of acid resistance of Salmonella typhimurium by exposure to short-chain fatty acids. Appl Environ Microbiol (1998) 64:3458-63.

120. Foster JW. Low $\mathrm{pH}$ adaptation and the acid tolerance response of Salmonella typhimurium. Crit Rev Microbiol (1995) 21:215-37. doi:10.3109/10408419509113541

121. Durant JA, Lowry VK, Nisbet DJ, Stanker LH, Corrier DE, Ricke SC. Short chain fatty acids alter HEp-2 cell association and invasion by stationary growth phase Salmonella typhimurium. J Food Sci (2000) 65:1206-9. doi:10. 1111/j.1365-2621.2000.tb10266.x

122. Durant JA, Corrier DE, Ricke SC. Short-chain volatile fatty acids modulate the expression of the hilA and invF genes of Salmonella typhimurium. J Food Prot (2000) 63:573-8. 
123. Huang CB, Alimova Y, Myers TM, Ebersole JL. Short- and medium-chain fatty acids exhibit antimicrobial activity for oral microorganisms. Arch Oral Biol (2011) 56:650-4. doi:10.1016/j.archoralbio.2011.01.011

124. Smulders FJM, Barendsen P, van Logtestijn JG, Mossel DAA, van der Marel GM. Review: lactic acid: considerations in favour of its acceptance as a meat decontaminant. Int J Food Sci Technol (1986) 21:419-36. doi:10.111/j.1365-2621.1986.tb00420.x

125. van Der Wielen PW, Biesterveld S, Notermans S, Hofstra H, Urlings BA, van Knapen F. Role of volatile fatty acids in development of the cecal microflora in broiler chickens during growth. Appl Environ Microbiol (2000) 66:2536-40. doi:10.1128/AEM.66.6.2536-2540.2000

126. Cook RH, Bird FH. Duodenal villus area and epithelial cellular migration in conventional and germ-free chicks. Poult Sci (1973) 52:2276-80. doi:10.3382/ ps. 0522276

127. Gordon HA, Bruckner-Kardoss E. Effect of normal microbial flora on intestinal surface area. Am J Physiol (1961) 201:175-8.

128. Naqi SA, Lewis DH, Hall CF. The intestinal microflora of turkeys. Avian Dis (1970) 14:620-5.

129. Round JL, Mazmanian SK. The gut microbiota shapes intestinal immune responses during health and disease. Nat Rev Immunol (2009) 9:313-23. doi:10.1038/nri2515

130. Talebi A, Amirzadeh B, Mokhtari B, Gahri H. Effects of a multi-strain probiotic (PrimaLac) on performance and antibody responses to Newcastle disease virus and infectious bursal disease virus vaccination in broiler chickens. Avian Pathol (2008) 37:509-12. doi:10.1080/03079450802356995

131. Salianeh N, Shirzad MR, Seifi S. Performance and antibody response of broiler chickens fed diets containing probiotic and prebiotic. J Appl Anim Res (2011) 39:65-7. doi:10.1080/09712119.2011.565222

132. Mohan B, Kadirvel R, Natarjan A, Bhaskaran M. Effect of probiotic supplementation on growth, nitrogen utilization and serum cholesterol in broilers. Br Poult Sci (1996) 37:395-401. doi:10.1080/00071669608417870

133. Sun Y, O'Riordan MX. Regulation of bacterial pathogenesis by intestinal short-chain fatty acids. Adv Appl Microbiol (2013) 85:93-118. doi:10.1016/ B978-0-12-407672-3.00003-4

134. Barnes EM, Mead GC, Barnum DA, Harry EG. The intestinal flora of the chicken in the period 2 to 6 weeks of age, with particular reference to the anaerobic bacteria. Br Poult Sci (1972) 13:311-26. doi:10.1080/00071667208415953

135. Shin MS, Han SK, Ji AR, Kim KS, Lee WK. Isolation and characterization of bacteriocin-producing bacteria from the gastrointestinal tract of broiler chickens for probiotic use. J Appl Microbiol (2008) 105:2203-12. doi:10.1111/j.1365-2672.2008.03935.x

136. Corrier DE, Nisbet DJ, Scanlan CM, Hollister AG, DeLoach JA. Control of Salmonella typhimurium colonization in broiler chicks with a continuous-flow characterized mixed culture of cecal bacteria. Poult Sci (1995) 74:916-24. doi:10.3382/ps.0741093

137. Nisbet DJ, Corrier DE, Ricke SC, Hume ME, Byrd JA II, DeLoach JR. Cecal propionic acid as a biological indicator of the early establishment of a microbial ecosystem inhibitory to Salmonella in chicks. Anaerobe (1996) 2:345-50. doi:10.1006/anae.1996.0044

138. Nisbet DJ, Corrier DE, Ricke SC, Hume ME, Byrd JA II, DeLoach JR. Maintenance of the biological efficacy in chicks of a cecal competitive-exclusion culture against Salmonella by continuous-flow fermentation. J Food Prot (1996) 59:1279-83.

139. Durant JA, Young CR, Nisbet DJ, Stanker LH, Ricke SC. Detection and quantification of poultry probiotic bacteria in mixed culture using monoclonal antibodies in an enzyme-linked immunosorbent assay. Int J Food Microbiol (1997) 38:181-9. doi:10.1016/S0168-1605(97)00102-5

140. Yu B, Liu JR, Hsiao FS, Chiou PWS. Evaluation of Lactobacillus reuteri Pg4 strain expressing heterologous $\beta$-glucanase as a probiotic in poultry diets based on barley. Anim Feed Sci Technol (2008) 141:82-91. doi:10.1016/j. anifeedsci.2007.04.010

141. Lin W-H, Yu B, Jang S-H, Tsen H-Y. Different probiotic properties for Lactobacillus fermentum strains isolated from swine and poultry. Anaerobe (2007) 13:107-13. doi:10.1016/j.anaerobe.2007.04.006

142. Santini C, Baffoni L, Gaggia F, Granata M, Gasbarri R, Di Gioia D, et al. Characterization of probiotic strains: an application as feed additives in poultry against Campylobacter jejuni. Int J Food Microbiol (2010) 141:S98-108. doi:10.1016/j.ijfoodmicro.2010.03.039
143. Owings WJ, Reynolds DL, Hasiak RJ, Ferket PR. Influence of dietary supplementation with Streptococcus faecium M-74 on broiler body weight, feed conversion, carcass characteristics, and intestinal microbial colonization. Poult Sci (1990) 69:1257-64. doi:10.3382/ps.0691257

144. Herrera P, O'Bryan CA, Crandall PG, Ricke SC. Growth response of Salmonella enterica typhimurium in co-culture with ruminal bacterium Streptococcus bovis is influenced by time of inoculation and carbohydrate substrate. Food Res Int (2012) 45:1054-7. doi:10.1016/j.foodres.2011.07.001

145. Walter J. Ecological role of lactobacilli in the gastrointestinal tract: implications for fundamental and biomedical research. Appl Environ Microbiol (2008) 74:4985-96. doi:10.1128/AEM.00753-08

146. Tannock GW. A special fondness for lactobacilli. Appl Environ Microbiol (2004) 70:3189-94. doi:10.1128/AEM.70.6.3189-3194.2004

147. Barnardeau M, Vernoux JP, Henri-Dubernet S, Guéguen M. Safety assessment of dairy microorganisms: the Lactobacillus genus. Int J Food Microbiol (2007) 126:278-85. doi:10.1016/j.ijfoodmicro.2007.08.015

148. Pot B, Tsakalidou E. Taxonomy and metabolism of Lactobacillus. In: Ljungh A, Wadström T, editors. Lactobacillus Molecular Biology: From Genomics to Probiotics. Norfolk: Caister Academic Press (2009). p. 3-58.

149. Lindegren SE, Dobrogosz WJ. Antagonistic activities of lactic acid bacteria in food and feed fermentations. FEMS Microbiol Rev (1990) 87:149-64. doi: 10.1111/j.1574-6968.1990.tb04885.x

150. Hammes WP, Vogel RF. The genus Lactobacillus. In Wood BJB and Holzapfel WH, editors. The Genera of Lactic Acid Bacteria, (Vol. 2) New York, NY: Chapman and Hall (1995). p. 19-54.

151. Bobillo M, Marshall VM. Effect of acidic $\mathrm{pH}$ and salt on acid end-products by Lactobacillus plantarum in aerated, glucose-limited continuous culture. $J$ Appl Microbiol (2008) 73:67-70. doi:10.1111/j.1365-2672.1992.tb04971.x

152. Pokusaeva K, Fitzgerald GF, van Sinderen D. Carbohydrate metabolism in Bifidobacteria. Genes Nutr (2011) 6:285-306. doi:10.1007/ s12263-010-0206-6

153. Van der Meulen R, Avonts L, De Vuyst L. Short fractions of oligofructose are preferentially metabolized by Bifidobacterium animalis DN-173 010. Appl Environ Microbiol (2004) 70:1923-30. doi:10.1128/ AEM.70.4.1923-1930.2004

154. Korakli M, Ganzle MG, Vogel RF. Metabolism by bifidobacteria and lactic acid bacteria of polysaccharides from wheat and rye, and exopolysaccharides produced by Lactobacillus sanfranciscensis. J Appl Microbiol (2002) 92:958-65. doi:10.1046/j.1365-2672.2002.01607.x

155. Lorenzoni G. Prebiotics. In: Lorenzoni G, editor. Poultry Diseases Influenced by Gastrointestinal Health: Traditional Treatments and Innovative Solutions. Nottingham: Nottingham University Press (2010). p. 36-8.

156. Stephenson DP, Moore RJ, Allison GE. Lactobacillus strain ecology and persistence within broiler chickens fed different diets: identification of persistent strains. Appl Environ Microbiol (2010) 76:6494-503. doi:10.1128/ AEM.01137-10

157. Jacobsen CN, Rosenfeldt-Nielsen V, Hayford AE, Møller PL, Micharlsen KF, Pærregaard A, et al. Screening of probiotics activities of forty-seven strains of Lactobacillus spp. by in vitro techniques and evaluation of the colonization ability of five selected strains in humans. Appl Environ Microbiol (1999) 65:4949-56.

158. Sandine WE. Role of Lactobacillus in the intestinal tract. J Food Prot (1979) 42:259-62.

159. Eklund T. The effect of carbon dioxide on bacterial growth and on uptake processes in bacterial membrane vesicles. Int J Food Microbiol (1984) 1:179-85. doi:10.1016/0168-1605(84)90014-X

160. Kaneuchi C, Seki M, Komagata K. Production of succinic acid from citric acid and related acids by Lactobacillus strains. Appl Environ Microbiol (1988) 54:3053-6.

161. Van der Meulen R, Adriany T, Verbrugghe K, De Vuyst L. Kinetic analysis of bifidobacterial metabolism reveals a minor role for succinic acid in the regeneration of $\mathrm{NAD}^{+}$through its growth-associated production. Appl Environ Microbiol (2006) 72:5204-10. doi:10.1128/AEM.00146-06

162. Gao Z, Shao J, Sun H, Zhong W, Zhuang W, Zhang Z. Evaluation of different kinds of organic acids and their antibacterial activity in Japanese apricot fruits. Afr J Agric Res (2012) 7:4911-8. doi:10.5897/AJAR12.1347

163. Yang LH, Lau SCK, Lee OO, Tsoi MMY, Qian PY. Potential roles of succinic acid against colonization by a tubeworm. J Exp Mar Bio Ecol (2007) 349:1-11. doi:10.1016/j.jembe.2007.03.016 
164. Jay JM. Antimicrobial properties of diacetyl. Appl Environ Microbiol (1982) 44:525-32.

165. Eyssen H, De Prins V, De Somer P. The growth-promoting action of virginiamycin and it influence on the crop flora in chickens. Poult Sci (1962) 41:227-33. doi:10.3382/ps.0410227

166. Zaidel O, Lin HC. Uninvited guests: the impact of small intestinal bacterial overgrowth on nutritional status. Pract Gastroenterol (2003) 7:27-34.

167. Herrera P, Kwon YM, Ricke SC. Ecology and pathogenicity of gastrointestinal Streptococcus bovis. Anaerobe (2009) 15:44-54. doi:10.1016/j. anaerobe.2008.11.003

168. Gibson GR, Probert HM, Van Loo J, Rastall RA, Roberfroid MB. Dietary modulation of the human colonic microbiota: updating the concept of prebiotics. Nutr Res Rev (2004) 17:259-75. doi:10.1079/NRR200479

169. Roberfroid MB. Prebiotics and probiotics: are they functional foods? Am J Clin Nutr (2000) 71:1682-7.

170. Wang X, Gibson GR. Effects of the in vitro fermentation of oligofructose and inulin by bacteria growing in the human large intestine. J Appl Bacteriol (1993) 75:373-80. doi:10.111/j.1365-2672.1993.tb02790.x

171. Delzenne NM, Roberfroid MB. Physiological effects of non-digestible oligosaccharides. LWT Food Sci Technol (1994) 27:1-6. doi:10.1006/ fstl.1994.1001

172. Marchessault RH, Blahe T, Deslandes Y, Revol J-F. Conformation and crystalline structure of ( $2 \diamond 1)-\beta$-D-fructofuranan (inulin). Can J Chem (1980) 58:2415-22. doi:10.1139/v80-390

173. Van Loo J, Coussement P, Leenheer LD, Hoebregs H, Smits G. On the presence of inulin and oligofructose as natural ingredients in the western diet. Crit Rev Food Sci Nutr (1995) 35:525-52. doi:10.1080/10408399509527714

174. Fishbein L, Kaplan M, Gough M. Fructooligosaccharides: a review. Vet Hum Toxicol (1988) 30:104-7.

175. Macfarlane S, Macfarlane GT, Cummings JH. Review article: prebiotics in the gastrointestinal tract. Aliment Pharmacol Ther (2006) 24:701-14. doi:10.1111/j.1365-2036.2006.03042.x

176. Kelly G. Inulin-type prebiotics - a review: part 1. Altern Med Rev (2008) 13:315-29.

177. Fuentes-Zaragoza E, Sánchez-Zapata E, Sendra E, Sayas E, Navarro C, Fernández-López J, et al. Resistant starch as prebiotic: a review. Starch (2011) 63:402-15. doi:10.1002/star.20100009

178. Ricke SC. Potential of fructooligosaccharide prebiotics in alternative and nonconventional poultry production systems. Poult Sci (2015) 94:1411-8. doi:10.3382/ps/pev049

179. Shen YB, Carroll JA, Yoon I, Mateo RD, Kim SW. Effects of supplementing Saccharomyces cerevisiae fermentation product in sow diets on performance of sows and nursing piglets. J Anim Sci (2011) 89:2462-71. doi:10.2527/ jas.2010-3642

180. Price KL, Totty HB, Lee HB, Utt MD, Fitzner GE, Yoon I, et al. Use of Saccharomyces cerevisiae fermentation product on growth performance and microbiota of weaned pigs during Salmonella infection. J Anim Sci (2010) 88:3896-908. doi:10.2527/jas.2009-2728

181. Gao J, Zhang HJ, Wu SG, Yu SH, Yoon I, Moore D, et al. Effect of Saccharomyces cerevisiae fermentation product on immune functions of broilers challenged with Eimeria tenella. Poult Sci (2009) 88:2141-51. doi:10.3382/ps.2009-00151

182. Duina A, Miller ME, Keeney JB. Budding yeast for budding geneticists: a primer on the Saccharomyces cerevisiae model system. Genetics (2014) 197:33-48. doi:10.1534/genetics.114.163188

183. Mortimer R. Evolution and variation of the yeast (Saccharomyces) genome. Genome Res (2000) 10:403-9. doi:10.1101/gr.10.4.403

184. Greig D, Leu JY. Natural history of budding yeast. Curr Biol (2009) 19:R88690. doi:10.1016/j.cub.2009.07.037

185. Mortimer RK, Johnston JR. Genealogy of principal strains of the yeast genetic stock center. Genetics (1986) 113:35-43.

186. Winston F, Dollard C, Ricupero-Hovasse SL. Construction of a set of convenient Saccharomyces cerevisiae strains that are isogenic to S288C. Yeast (1995) 11:53-5. doi:10.1002/yea.320110107

187. Goffeau A, Barrell BG, Bussey H, Davis RW, Dujun B, Feldmann H, et al. Life with 6000 genes. Science (1996) 274: 563-6. doi:10.1126/ science.274.5287.546
188. Botstein D, Fink GR. Yeast: an experimental organism for modern biology. Science (1988) 240:1439-43. doi:10.1126/science.3287619

189. Botstein D, Chervitz SA, Cherry JM. Yeast as a model organism. Science (1997) 277:1259-60. doi:10.1126/science.277.5330.1259

190. Caspeta L, Chen Y, Ghiaci P, Feizi A, Buskov S, Hallström BM. Altered sterol composition renders yeast thermotolerant. Science (2014) 346:75-8. doi:10.1126/science.1258137

191. Liu Y, Zhang G, Sun H, Sun X, Jiang N, Rasool A, et al. Enhanced pathway efficiency of Saccharomyces cerevisiae by introducing thermo-tolerant devices. Bioresour Technol (2014) 170:38-44. doi:10.1016/j. biortech.2014.07.063

192. Botstein D, Fink GR. Yeast: an experimental organism for $21^{\text {st }}$ century biology. Genetics (2011) 189:695-704. doi:10.1534/genetics.111.130765

193. Gershon H, Gershon D. The budding yeast, Saccharomyces cerevisiae, as a model for aging research: a critical review. Mech Ageing Dev (2000) 120:1-22. doi:10.1016/S0047-6374(00)00182-2

194. Mager WH, Winderickx J. Yeast as a model for medical and medicinal research. Trends Pharmacol Sci (2005) 26:265-73. doi:10.1016/j.tips.2005.03.004

195. Siddiqui MS, Thodey K, Trenchard I, Smolke CD. Advancing secondary metabolite biosynthesis in yeast with synthetic biology tools. FEMS Yeast Res (2012) 12:144-70. doi:10.1111/j.1567-1364.2011.00774.x

196. Sherman F. Getting started with yeast. Methods Enzymol (2002) 250:3-41. doi:10.1016/S0076-6879(02)50954-X

197. Bisson LF. Yeast-metabolism of sugars. In: Fleet GH, editor. Wine Microbiology and Biotechnology. Chur: Harwood Academic Publishers (1993). p. 55-75.

198. Denev SA, Peeva T, Radulova P, Stancheva P, Staykova G, Beev G, et al. Yeast cultures in ruminant nutrition. Bulg J Agric Sci (2007) 13:357-74.

199. Lyons TP, Jacques KA, Dawson KA. Miscellaneous products from yeasts. 2nd ed. In: Rose AH, Harrison JS, editors. The Yeasts, Volume 5. Yeast Technology. London: Academis (2012). p. 293-325.

200. Buzzini P, Vaughn-Martini A. Yeast biodiversity and biotechnology. In: Rosa CA, Péter G, editors. Biodiversity and Ecophysiology of Yeasts. Berlin: Springer (2006). p. 533-60.

201. Grant CL, Pramer D. Minor element composition of yeast extract. J Bacteriol (1962) 84:869-70.

202. Charpentier C, Feuillat M. Yeast autolysis. In: Fleet GH, editor. Wine Microbiology and Biotechnology. Chur: Harwood Academic Publishers (1993). p. 225-42.

203. Moon S-K, Lee J, Song H, Cho J-H, Choi G-W, Seung D. Characterization of ethanol fermentation waste and its application to lactic acid production by Lactobacillus paracasei. Bioprocess Biosyst Eng (2013) 36:547-54. doi:10.1007/ s00449-012-0810-5

204. Jouany JP. A new look at yeast cultures as probiotics for ruminants. Feed Mix (2001) 9:17-9.

205. Fonty G, Chaucheyras-Durand F. Effects and modes of action of live yeasts in the rumen. Biologia (2006) 61:741-50. doi:10.2478/s11756-006-0151-4

206. Singh SK, Niranjan PS, Singh UB, Koley S, Verma DN. Effects of dietary supplementation of probiotics on broiler chicken. Anim Nutr Feed Technol (2009) 9:85-90.

207. de Oliva Neto P, Amorim Ferreira M, Yokoya F. Screening for yeast with antibacterial properties from an ethanol distillery. Bioresour Technol (2004) 92:1-6. doi:10.1016/j.biortech.2003.08.005

208. Dawson KA, Newman KE, Boling JA. Effects of microbial supplements containing yeast and lactobacilli on roughage-fed ruminal microbial activities. $J$ Anim Sci (1990) 68:3392-8.

209. Czerucka D, Piche T, Rampal P. Review article: yeast as probiotics - Saccharomyces boulardii. Aliment Pharmacol Ther (2007) 26:767-78. doi:10.1111/j.1365-2036.2007.03442.x

210. Elmer GW, Corthier G. Modulation of Clostridium difficile induced mortality as a function of the dose and the viability of the Saccharomyces boulardii used as a preventative agent in gnotobiotic mice. Can J Microbiol (1991) 37:315-7. doi:10.1139/m91-049

211. Buts J-P, Bernasconi P, Van Craynest M-P, Maldague P, De Meyer R. Response of human and rat small intestinal mucosa to oral administration of Saccharomyces boulardii. Pediatr Res (1986) 20:192-6. doi:10.1203/00006450-198602000-00020 
212. Newbold CJ, Wallace RJ, McIntosh FM. Mode of action of the yeast Saccharomyces cerevisiae as a feed additive for ruminants. Br J Nutr (1996) 76:249-61. doi:10.1079/BJN19960029

213. Santin E, Maiorka A, Macari M, Grecco M, Sanchez JC, Okada TM. Performance and intestinal mucosa development of broiler chickens fed diets containing Saccharomyces cerevisiae cell wall. J Appl Poult Res (2001) 10:236-44. doi:10.1093/japr/10.3.236

214. Zhang AW, Lee BD, Lee SK, Lee KW, An GH, Song KB, et al. Effects of yeast (Saccharomyces cerevisiae) cell components on growth performance, meat quality, and ileal mucose development of broiler chicks. Poult Sci (2005) 84:1015-21. doi:10.1093/ps/84.7.1015

215. Firman JD, Moore D, Broomhead J, McIntyre D. Effects of dietary inclusion of a Saccharomyces cerevisiae fermentation product on performance and gut characteristics of male turkeys to market weight. Int J Poult Sci (2013) 12:141-3. doi:10.3923/ijps.2013.141.143

216. Gao J, Zhang HJ, Yu SH, Wu SG, Yoon I, Quigley J, et al. Effects of yeast culture in broiler diets on performance and immunomodulatory functions. Poult Sci (2008) 87:1377-84. doi:10.3382/ps.2007-00418

217. Shareef AM, Al-Dabbagh ASA. Effect of probiotic (Saccharomyces cerevisiae) on performance of broiler chicks. Iraqi J Vet Sci (2009) 23:23-9. doi:10.3382/ ps.2012-02846

218. Bradley GL, Savage TF, Timm KI. The effects of supplementing diets with Saccharomyces cerevisiae var. boulardii on male poult performance and ileal morphology. Poult Sci (1994) 73:1766-70. doi:10.3382/ ps.0731766

219. El-Husseiny OM, Abdallah AG, Abdel-Latiff KO. The influence of biological feed additives on broiler performance. Int J Poult Sci (2008) 7:862-71. doi:10.3923/ijps.2008.862.871

220. Al-Homidan A, Fahmy MO. The effect of dried yeast (Saccharomyces cerevisiae) supplementation on growth, performance, carcass chemical analysis, immunity, ileum villi heights and bacterial counts of broiler chickens. Egypt Poult Sci J (2007) 27:613-23.

221. Spring P, Wenk C, Dawson KA, Newman KE. The effects of dietary mannanoligosaccharides on cecal parameters and the concentrations of enteric bacteria in the ceca of Salmonella-challenged broiler chicks. Poult Sci (2000) 79:205-11. doi:10.1093/ps/79.2.205

222. Loddi MM, Nakaghi LSO, Edens F, Tucci FM, Hannas MI, Moraes VMB, et al. Mannanoligosaccharides and organic acids on intestinal morphology integrity of broilers evaluated by scanning electron microscopy. In: Proceedings of the 11th European Poultry Science Conference, Bremen (2002). p. 121.

223. HoffmanOA,OlsonEJ,LimperAH.Fungalbeta-glucansmodulatemacrophage release of tumor necrosis factor-alpha in response to bacterial lipopolysaccharide. Immunol Lett (1993) 37:19-25. doi:10.1016/0165-2478(93)90127-N

224. Hooge D. Meta-analysis of broiler chicken pen trials evaluating dietary mannan oligosaccharide, 1993-2003. Int J Poult Sci (2004) 3:163-71. doi:10.3923/ ijps.2004.163.174

225. Rosen GD. Holo-analysis of the efficacy of Bio-Mos ${ }^{\circledR}$ in broiler nutrition. $\mathrm{Br}$ Poult Sci (2007) 48:21-6. doi:10.1080/00071660601050755

226. Peuranen S, Kogher A, Dawson KA. Yeast cell wall preparations prevent the attachment of enteropathogenic Escherichia coli on broiler gut mucus. Reprod Nutr Dev (2006) 46:S111.

227. Line JE, Bailey JS, Cox NA, Stern NJ, Tompkins T. Effect of yeast-supplemented feed on Salmonella and Campylobacter populations in broilers. Poult Sci (1998) 77:405-10. doi:10.1093/ps/77.3.405

228. Yang Y, Iji PA, Kocher A, Thomson E, Mikkelsen LL, Choct M. Effects of mannanoligosaccharide in broiler chicken diets on growth performance, energy utilization, nutrient digestibility and intestinal microflora. Br Poult Sci (2008) 49:186-94. doi:10.1080/00071660801998613

229. Paryad A, Mahmoudi M. Effect of different levels of supplemental yeast (Saccharomyces cerevisiae) on performance, blood constituents and carcass characteristics of broilers chicks. Afr J Agric Res (2008) 3:835-42.

230. Tripathi MK, Karim SA. Effect of individual and mixed live yeast culture feeding on growth performance, nutrient utilization and microbial crude protein synthesis in lambs. Anim Feed Sci Technol (2010) 155:163-71. doi:10.1016/j.anifeedsci.2009.11.007

231. Adebiyi OA, Makanjuola BA, Bankole TO, Adeyori AS. Yeast culture (Saccharomyces cerevisiae) supplementation: effect on the performance and gut morphology of broiler birds. Global J Sci Front Res Biol Sci (2012) 12:25-9.

232. Tripathi MK, Karim SA, Chaturvedi OH, Verma DL. Effect of different liquid cultures of live yeast strains on performance, ruminal fermentation and microbial protein synthesis in lambs. J Anim Physiol Anim Nutr (2007) 92:631-9. doi:10.1111/j.1439-0396.2007.00759.x

233. Sporn MB, Dunlop NM, Newton DL, Smith JM. Prevention of chemical carcinogenesis by vitamin A and its synthetic analogs (retinoids). Fed Proc (1976) 35:1332-8.

234. Wyss A, Wirtz G, Woggon W-D, Brugger R, Wyss M. Cloning and expression of $\beta, \beta$-carotene 15,15'-dioxygenase. Biochem Biophys Res Commun (2000) 271:334-6. doi:10.1006/bbrc.2000.2619

235. Wyss A. Carotene oxygenases: a new family of double bond cleavage enzymes. J Nutr (2004) 134:246S-50S.

236. Yamano S, Ishii T, Nakagawa M, Ikenaga H, Misawa N. Metabolic engineering for production of $\beta$-carotene and lycopene in Saccharomyces cerevisiae. Biosci Biotechnol Biochem (1993) 58:1112-4. doi:10.1271/bbb.58.1112

237. Arnezeder C, Hampel WA. Influence of growth rate on the accumulation of ergosterol in yeast-cells. Biotechnol Lett (1990) 12:277-82. doi:10.1007/ BF01093521

238. Parks LW, Casey WM. Physiological implications of sterol biosynthesis in yeast. Annu Rev Microbiol (1995) 49:95-116. doi:10.1146/annurev. mi.49.100195.000523

239. Shang F, Wen S, Wang X, Tan T. Effect of nitrogen limitation on the ergosterol production by fed-batch culture of Saccharomyces cerevisiae. J Biotechnol (2006) 122:285-92. doi:10.1016/j.jbiotec.2005.11.020

240. Scanes CG, Harvey S, Marsh JA, King DB. Hormones and growth in poultry. Poult Sci (1984) 63:2062-74. doi:10.3382/ps.0632062

241. Hancock RD, Galpin JR, Viola R. Biosynthesis of L-ascorbic acid (vitamin C) by Saccharomyces cerevisiae. FEMS Microbiol Lett (2000) 186:245-50. doi:10 .1111/j.1574-6968.2000.tb09112.x

242. Ferket PR, Qureshi MA. Performance and immunity of heat-stressed broilers fed vitamin- and electrolyte-supplemented drinking water. Poult Sci (1992) 71:88-97. doi: 10.3382/ps.0710088

243. Öztürk-Ürek R, Bozkaya LA, Tarhan L. The effects of some antioxidant vitamin- and trace element-supplemented diets on activities of SOD, CAT, GSH-Px and LPO levels in chicken tissues. Cell Biochem Funct (2001) 19:125-32. doi:10.1002/cbf.905

244. Young JF, Stagsted J, Jensen SK, Karlsson AH, Henckel P. Ascorbic acid, $\alpha$-tocopherol, and oregano supplements reduce stress-induced deterioration of chicken meat quality. Poult Sci (2003) 82:1343-51. doi:10.1093/ps/82.8.1343

245. Jakobsen M, Narvhus J. Yeasts and their possible beneficial and negative effects on the quality of dairy products. Int Dairy J (1996) 6:755-68. doi:10.1016/0958-6946(95)00071-2

246. Jones EW. Three proteolytic systems in the yeast Saccharomyces cerevisiae. J Biol Chem (1991) 266:7963-6.

247. Harvey RB, Norman KN, Andrews K, Hume ME, Scanlan CM, Callaway TR, et al. Clostridium difficile in poultry and poultry meat. Foodborne Pathog Dis (2011) 8:1321-3. doi:10.1089/fpd.2011.0936

248. McCullough MJ, Clemons KV, McHusker JH, Stevens DA. Species identification and virulence attributes of Saccharomyces boulardii (nom. inval.). J Clin Microbiol (1998) 36:2613-7.

249. Pothoulakis C, Kelly CP, Joshi MA, Gao N, O’Keane CJ, Castagliuolo I, et al. Saccharomyces boulardii inhibits Clostridium difficile toxin A binding and enterotoxicity in rat ileum. Gastroenterology (1993) 104:1108-15.

250. Castagliuolo I, LaMont JT, Nikulasson ST, Pothoulakis C. Saccharomyces boulardii protease inhibits Clostridium difficile toxin A effects in the rat ileum. Infect Immun (1996) 64:5225-32.

251. Buts J-P, Bernasconi P, Vaerman J-P, Dive C. Stimulation of secretory IgA and secretory component of immunoglobulins in small intestine of rats treated with Saccharomyces boulardii. Dig Dis Sci (1990) 35:251-6. doi:10.1007/ BF01536771

252. Shankar T, Thangamathi P, Rama R, Sivakumar T. Optimization of invertase production using Saccharomyces cerevisiae MK under varying cultural conditions. Int J Biochem Biophys (2013) 1:47-53. doi:10.13189/ ijbb.2013.0101301

253. Walker GM. Yeast Physiology and Biotechnology. Chichester: Wiley (1998). 78 p. 
254. Almquist HJ. Amino acid requirements of chickens and turkeys - a review. Poult Sci (1952) 31:966-81. doi:10.3382/ps.0310966

255. Aletor VA, Hamid II, Nieß E, Pfeffer E. Low-protein amino acid-supplemented diets in broiler chickens: effects on performance, carcass characteristics, whole body composition and efficiencies of nutrient utilisation. J Sci Food Agric (2000) 80:547-54. doi:10.1002/ (SICI) 1097-0010(200004)80:5<547::AID-JSFA531>3.0.CO;2-C

256. Sibbald IR, Wolynetz MS. Effects of dietary lysine and feed intake on energy utilization and tissue synthesis by broiler chicks. Poult Sci (1986) 65:98-105. doi:10.3382/ps.0650098

257. Gasent-Ramírez JM, Benítez T. Lysine-overproducing mutants of Saccharomyces cerevisiae baker's yeast isolated in continuous culture. Appl Environ Microbiol (1997) 63:4800-6.

258. Bevan EA, Makower M. The physiological basis of the killer character in yeast. Proc 11th Int Conf Genet (1963). 1:202-3.

259. Walker GM, McLeod AH, Hodgson VJ. Interactions between killer yeasts and pathogenic fungi. FEMS Microbiol Lett (1995) 127:213-22. doi:10.111/j.1574-6968.1995.tb07476.x

260. Marquina D, Santos A, Peinado JM. Biology of killer yeasts. Int Microbiol (2002) 5:65-71. doi:10.1007/s10123-002-0066-z
261. Polonelli L, Morace G. Reevaluation of the yeast killer phenomenon. J Clin Microbiol (1986) 24:866-9.

262. Stanley D, Hughes RJ, Moore RJ. Microbiota of the chicken gastrointestinal tract: influence on health, productivity and disease. Appl Microbiol Biotechnol (2014) 98:4301-10. doi:10.1007/s00253-014-5646-2

263. Schrezemmeir J, de Vrese M. Probiotics, prebiotics, and synbiotics - approaching a definition. Am J Clin Nutr (2001) 73:361S-4S.

Conflict of Interest Statement: The authors declare that the research was conducted in the absence of any commercial or financial relationships that could be construed as a potential conflict of interest.

Copyright $(02015$ Roto, Rubinelli and Ricke. This is an open-access article distributed under the terms of the Creative Commons Attribution License (CC BY). The use, distribution or reproduction in other forums is permitted, provided the original author(s) or licensor are credited and that the original publication in this journal is cited, in accordance with accepted academic practice. No use, distribution or reproduction is permitted which does not comply with these terms. 